\title{
Kualitas Data dalam Riset Akuntansi Manajemen dan Keperilakuan: Bukti Empiris dari Metode Survei di Indonesia
}

\author{
Y. Anni Aryani1 ${ }^{*}$; Setianingtyas Honggowati ${ }^{1}$; Djuminah ${ }^{1}$; Agnes Utari Widyaningdyah ${ }^{2}$ \\ ${ }^{1}$ Universitas Sebelas Maret Surakarta, Jl. Ir. Sutami 36 A, Surakarta 57126, Jawa Tengah \\ ${ }^{2}$ Universitas Widya Mandala Surabaya Л. Dinoyo 48A, Surabaya 60265, Jawa Timur \\ * Korespondensi penulis, email: y_anniar@yahoo.com
}

\begin{abstract}
ABSTRAK
Metode survei merupakan salah satu metode yang digunakan dalam penelitian akuntansi manajemen dan keperilakuan. Namun demikian, metode ini telah mendapat banyak kritik terutama berkaitan dengan kualitas data. Studi ini menguji kualitas penelitian dalam bidang akuntansi manajemen dan keperilakuan. Rerangka yang digunakan dalam studi ini merujuk pada Van der Stede et al. (2005) yang menguji kualitas dari seluruh mail survey dalam penelitian akuntansi manajemen dan keperilakuan yang dipublikasikan dalam proceeding Simposium Nasional Akuntansi (SNA) periode 1999-2012. Hasil analisis menunjukkan bahwa sebagian besar artikel telah menggunakan prinsip-prinsip dasar yang disarankan dalam melakukan penelitian survei, walaupun masih terdapat beberapa hal yang membutuhkan perhatian dalam rangka meningkatkan kualitas data survei.
\end{abstract}

Kata kunci: Kualitas data, metode survei, manajemen akuntansi dan perilaku.

\begin{abstract}
Survey method is one of the research methods employed in management accounting and behavior research. However, this method has been heavily criticized especially regarding the quality to the data. This study examines the quality of survey research in management accounting and behavior. We use a framework that has been used by Van der Stede et al. (2005) to examine the quality of all mail surveys in management accounting and behavior published in proceeding of Simposium Nasional Akuntansi (SNA) over a period of year 1999-2012. Our analysis shows that most of those articles have employed suggested fundamental principles of conducting survey research, although there are still more attentions should be taken place to increase the quality of data survey.
\end{abstract}

Keywords: Data quality, survey method, management accounting and behavior.

\section{PENDAHULUAN}

Dalam ilmu sosial, metode survei merupakan salah satu metode yang banyak digunakan untuk meneliti secara empiris berbagai karakteristik dan hubungan berbagai variabel-variabel sosiologi dan psikologi (Roberts 1999; Nazari et al. 2006). Perkembangan dan penggunaan metode survei dalam abad 20an telah sangat mempengaruhi perkembangan ilmu sosial (Kerlinger 1986). Metode survei mempunyai banyak manfaat misalnya merupakan metode pengumpulan data dalam jumlah besar untuk keperluan generalisasi data dengan biaya yang relatif rendah (cost-effective) dan dapat menghindari bias interview (Roberts 1999).
Riset akuntansi manajemen dan keperilakuan sebagai bagian dari ilmu sosial juga banyak menggunakan metode survei. Metode survei tepat untuk riset tersebut karena biasanya data dalam riset akuntansi manajemen dan keperilakuan berupa self-report. Nazari et al. (2006) menyatakan bahwa ada beberapa asumsi dalam riset dengan metode survei yang menggunakan self-report dari perilaku, nilai, kepercayaan, opini dan/atau maksud seseorang dalam hal ini para responden atau partisipan dalam penelitian. Asumsi-asumsi tersebut adalah: pertama, responden merupakan sumber yang paling terpercaya untuk informasi tertentu. Kedua, persepsi subyektif sesungguhnya merupakan hal yang penting. Ketiga, persepsi dapat digambarkan mempunyai hubungan dengan 
outcomes yang merupakan perhatian dari suatu organisasi (Nazari et al., 2006).

Namun demikian, metode ini tidak bebas dari berbagai kritikan (Marsh 1982; de Vaus 1992). Lebih lanjut, Young (1996) mempertanyakan kontribusinya terhadap riset akuntansi manajemen. Perhatian utama yang mendasari berbagai kritik tersebut adalah masalah validitas dan reliabilitas dari metode survei (Van der Stede, Young dan Chen 2005; Young 1996). Oleh karena itu, untuk meminimalkan masalah yang mungkin timbul, setiap usaha seharusnya dilakukan untuk memperolah data yang berkualitas. Pentingnya kualitas data dengan metode survei ini memunculkan pertanyaan bagaimanakah kualitas data dengan metode survei dalam bidang akuntansi manajemen dan keperilakuan yang sudah dilakukan di Indonesia selama ini?

Sebagai sebuah metode pengumpulan data penelitian yang cukup populer terutama pada penelitian bidang akuntansi manajemen dan keperilakuan, metode survei merupakan metode penelitian yang penting. Sebagai sebuah metode pengumpulan data, maka data yang diperoleh haruslah berkualitas sehingga hasil kesimpulan yang diambil dari penelitian tersebut juga berkualitas. Permasalahan muncul ketika metode survei tersebut tidak dilakukan dengan baik dan benar, dalam arti tidak dilakukan dengan mengikuti prosedur yang semestinya sesuai pedoman penelitian ilmiah yang ada. Akibatnya tidak mengherankan bahwa banyak kritikan yang terlontar mengenai kualitas data penelitian yang dilakukan dengan metode survei. Oleh karena itu, penelitian ini dilakukan untuk mengetahui bagaimana penelitian dengan metode survei dilakukan di Indonesia. Hal ini penting untuk dilakukan sehingga kita dapat mengetahui dan menjawab berbagai kritikan mengenai kualitas data yang dilakukan dengan metode survei. Sepengetahuan kami, penelitian semacam ini belum pernah dilakukan di Indonesia. Dengan menggunakan data dari semua survei dalam riset akuntansi manajemen dan keperilakuan yang terdapat dalam proceeding simposium nasional akuntansi (SNA) 1 - SNA 15 (2012), kami menemukan bahwa sebagian besar peneliti sudah melakukan prosedur penelitian survei sesuai prinsip-prinsip mendasar yang disarankan sehingga kualitas data yang digunakan dalam penelitian cukup dapat dipertanggung jawabkan, meskipun masih ada beberapa hal yang mungkin masih perlu diperbaiki untuk meningkatkan kualitas data dari metode survei.

\section{Metode Survei}

Seperti yang sudah disinggung dalam pendahuluan, survei merupakan metode penelitian yang banyak memperoleh kritikan. Kritikan tersebut pada dasarnya ditujukan pada reliabilitas data yang diperoleh dari metode survei (Young
1996). Penelitian terdahulu telah mengidentifikasi bahwa sumber dari berbagai kritikan tersebut bukanlah pada metodenya sendiri, melainkan labih pada kegagalan peneliti dalam mengikuti dan mengimplementasikan berbagai prinsip dasar metode survei tertutama dalam hal perancangan survei dan administrasinya (Mangione 1995; Van der Stede et al. 2005). Jika survei dirancang dan dilakukan dengan benar maka metode ini akan dapat menjadi metode untuk memperoleh sumber data dengan skala besar dan berkualitas tinggi. Oleh karena itu kualitas data sangat penting dalam riset menggunakan metode survei.

Di dalam riset akuntansi manajemen, survei seringkali digunakan untuk menguji teori, meskipun seringkali juga digunakan untuk tujuan diskriptif. Nazari et al. (2006) menyatakan bahwa tujuan riset survei dalam akuntansi manajemen adalah untuk mengukur perilaku tertentu dari suatu populasi atau suatu sampel, dan dapat digunakan baik untuk tujuan riset eksploratori maupun konfirmatori. Riset eksploratori adalah suatu riset untuk menemukan fakta-fakta dasar dan membiasakan dengan subjek dalam penelitian. Pada umumnya penelitian eksploratori berfokus pada penemuan tentang konstruk apa yang harus diukur dan bagaimana mengukurnya (Pinsonneault dan Kraemer 1993). Di lain pihak, riset konfirmatori merupakan uji teori yang menguji hubungan antara berbagai konstruk yang telah didefinisikan dalam penelitian-penelitian sebelumnya (Nazari et al. 2006).

Seperti telah dibahas di atas bahwa meskipun metode survei seringkali digunakan tetapi ada keraguan mengenai kualitas data yang dikumpulkan dengan metode tersebut. Zimmerman (2001) menyatakan bahwa data yang diperoleh dengan metode survei seringkali berkualitas buruk karena adanya masalah bias yang berasal baik dari responden maupun dari peneliti itu sendiri. Meskipun demikian, Van der Stede et al. (2005) mengatakan bahwa masalah itu bisa diatasi oleh peneliti dengan cara mengimplementasikan beberapa teknik. Sebagai contoh: peneliti dapat mengatasi masalah tersebut dengan cara merancang survei dengan mengembangkan kuesioner yang 'benar' sesuai dengan tujuan penelitian. Cara yang lain misalnya peneliti berusaha meningkatkan response rate dengan cara melakukan prosedur follow-up, dan sebagainya. Sehingga dengan berbagai cara tersebut masalah bisa diatasi dan kualitas data dapat ditingkatkan.

\section{Metode Survei dengan Mail Questionnaire}

Ada beberapa tipe riset yang menggunakan metode survei, misalnya: (1) survei dengan menggunakan pihak-ketiga (sebagai contoh: Ittner dan Larcker 1995, 1997), (2) survei sebagai bagian atau kombinasi dengan case-method (sebagai contoh: Berry, Loughton, dan Otley 1991), lab experiments 
(sebagai contoh: Brownell 1982a), atau interviewprotocols (sebagai contoh: Chenhall 1997), (3) survei yang dilakukan pada saat on-site interview (sebagai contoh: Brownell 1982b) atau di dalam setting kelas (dengan mahasiswa) (sebagai contoh: Hirst 1983), (4) survei yang dilakukan secara langsung (face-to-face) (sebagai contoh: McGowan dan Klammer 1997) atau melalui telepon (sebagai contoh: Swenson 1995), dan (5) survei yang dilakukan dengan menggunakan kuesioner yang dikirim melalui pos (mail questionnaire) (sebagai contoh: Moores dan Yuen 2001, Kalagnanam dan Lindsay 1999, dan Aryani 2009). Namun demikian fokus penelitian ini adalah metode survei dengan menggunakan mail-questionnaire dengan penjelasan sebagai berikut.

Kuesioner yang dikirimkan kepada responden dengan melalui pos (mail questionnaire) merupakan salah satu teknik pengumpulan data yang banyak dikritik karena kemungkinan rendahnya response dan ketidakmampuannya memverifikasi response yang diberikan (Kerlinger dan Lee 2000). Meskipun demikian, jumlah survei yang dilakukan dengan cara ini (mail questionnaires) semakin meningkat dan melebihi jumlah survei dengan interviu yang dilakukan setiap tahun, meskipun sukar untuk menyebut jumlah pastinya (Dillman 2007). Dalam riset akuntansi manajemen, survei dengan kuesioner melalui pos (mail questionnaire) adalah metode survei yang paling banyak digunakan (Van der Stede et al. 2005). Sehingga dalam penelitian ini hanya akan difokuskan pada analisa kualitas data survei dengan menggunakan kuesioner yang dikirim lewat pos (mail-questionnaire).

\section{Framework yang Digunakan}

Penelitian ini dilakukan untuk mengetahui kualitas data dalam riset akuntansi manajemen dan keperilakuan yang menggunakan mail questionnaire. Dalam melakukan analisa mengenai kualitas data tersebut digunakan suatu framework yang telah digunakan dalam penelitian-penelitian terdahulu. Terdapat beberapa framework yang dapat digunakan untuk menilai kualitas data riset dengan metode mail questionnaire, misalnya framework-nya Dillman (1978, 1999, 2007), Cook dan Campbell (1979), atau Diamond, 2000 yang telah digunakan oleh Van der Stede et al. (2005).

Mengikuti penelitian Van der Stede et al. (2005), framework yang digunakan untuk menguji kualitas data dalam penelitian ini adalah framework Diamond 2000 dengan modifikasi menggunakan guideline dari Dillman (2007) untuk menganalisis karakteristik dari tiap penelitian yang digunakan dalam sampel. Framework yang digunakan tersebut meliputi lima kategori umum yaitu: (1) tujuan dan rancangan survei dengan mail questionnaire, dalam sub-bab ini kami menganalisis perancangan riset dan level unit analisis;
(2) definisi populasi dan sampling, dalam sub-bab ini kami menganalisis mengenai populasi survei dan ukuran sampel; (3) pertanyaan survei dan masalah-masalah metode riset yang lain, dalam kategori ini kami melakukan analisis mengenai prosedur pre-test, response-rate, prosedur follow-up, non-response bias, dan tipe ukuran dependen variabel; (4) keakuratan entry data, dan (5) penyajian dan pelaporan.

\section{METODE PENELITIAN}

\section{Populasi dan Sampel}

Populasi yang digunakan dalam penelitian ini adalah semua artikel (paper) yang dipublikasikan dalam proceeding Simposium Nasional Akuntansi (SNA) dari tahun pertama sampai dengan tahun ke-15 (2012). Sedangkan sampel dalam penelitian ini adalah semua artikel dalam bidang akuntansi manajemen dan keperilakuan yang menggunakan metode survei dengan kuesioner yang dikirim melalui pos (mail questionnaire). Alasan digunakannya proceeding SNA adalah karena SNA merupakan ajang bergengsi seminar nasional akuntansi pertama yang diselenggarakan oleh Ikatan Akuntan Indonesia Kompartemen Akuntan Pendidik (IAI KAPd) bekerja sama dengan universitas di seluruh Indonesia dengan reviewer para akuntan yang bergerak dalam bidang pendidikan dan penelitian dari seluruh Indonesia. Dengan demikian diharapkan bahwa semua paper yang lolos untuk dipresentasikan dalam SNA merupakan paper yang mempunyai kualitas tinggi yang kemudian dipublikasikan dalam proceeding SNA. Selain hal tersebut, proceeding SNA juga telah menjadi salah satu acuan yang sering dikutip oleh peneliti-peneliti dalam bidang akuntansi di Indonesia. Sehingga menjadi sangat penting untuk mengetahui kualitas data riset akuntansi manajemen dan keperilakuan dengan menggunakan mail questionnaire pada proceeding SNA tersebut. Artikel-artikel dalam bidang akuntansi manajemen dan keperilakuan tersebut akan dianalisis menggunakan framework yang telah digunakan oleh Van der Stede et al. (2005).

\section{HASIL PENELITIAN DAN PEMBAHASAN}

Menggunakan framework dan karakteristik yang telah dijelaskan di atas, penelitian ini menganalisis riset survei dalam bidang akuntansi manajemen dan keperilakuan selama jangka waktu 15 tahun sejak SNA pertama hingga SNA 15 (tahun 2012) dengan fokus analisis pada survei dengan mail questionnaire. Tabel 1 memperlihatkan jumlah penelitian empiris di bidang akuntansi manajemen dan keperilakuan dengan menggunakan metode survei secara umum maupun secara khusus dengan mail questionnaire selama jangka 
waktu 15 tahun sejak SNA pertama tahun 1997 hingga SNA 15 tahun 2012.

Tabel 1. Persentasi penelitian survei bidang akuntansi manajemen dan keperilakuan di SNA 1-15 (tahun 1997-2012)

\begin{tabular}{ccrrrr}
\hline \multirow{2}{*}{ SNA } & Tahun & $\begin{array}{c}\text { Total penelitian } \\
\text { survei }\end{array}$ & $\begin{array}{c}\text { Penelitian survei } \\
\text { dengan mail } \\
\text { questionnaire }\end{array}$ \\
\cline { 3 - 6 } & & Jumlah & $\%$ & Jumlah & $\%$ \\
\hline 1 & 1997 & 0 & 0 & 0 & 0 \\
2 & 1999 & 12 & $4 \%$ & 8 & $8 \%$ \\
3 & 2000 & 9 & $3 \%$ & 5 & $5 \%$ \\
4 & 2001 & 13 & $4 \%$ & 7 & $7 \%$ \\
5 & 2002 & 20 & $7 \%$ & 8 & $8 \%$ \\
6 & 2003 & 35 & $12 \%$ & 16 & $15 \%$ \\
7 & 2004 & 16 & $6 \%$ & 7 & $7 \%$ \\
8 & 2005 & 24 & $8 \%$ & 11 & $10 \%$ \\
9 & 2006 & 37 & $13 \%$ & 13 & $12 \%$ \\
10 & 2007 & 4 & $1 \%$ & 2 & $2 \%$ \\
11 & 2008 & 23 & $8 \%$ & 4 & $4 \%$ \\
12 & 2009 & 16 & $6 \%$ & 4 & $4 \%$ \\
13 & 2010 & 33 & $11 \%$ & 8 & $8 \%$ \\
14 & 2011 & 20 & $7 \%$ & 4 & $4 \%$ \\
15 & 2012 & 28 & $10 \%$ & 9 & $8 \%$ \\
\hline & & 290 & $100 \%$ & 106 & $100 \%$ \\
\hline
\end{tabular}

Dari Tabel 1 tersebut, terlihat bahwa perkembangan penelitian empiris di bidang akuntansi manajemen dan keperilakuan dengan menggunakan survei mail questionnaire relatif stabil dari tahun ke tahun. Pada SNA 1 tahun 1997 hanya ada satu bidang penelitian yaitu bidang akuntansi keuangan sehingga tidak ada penelitian empiris yang menggunakan metode survei. Metode mail questionnaire paling banyak digunakan pada SNA 6 tahun 2003 yaitu 16 penelitian (15\%) dilanjutkan dengan SNA 9 tahun 2006 (12\%) dan SNA 8 tahun 2005 (10\%), selebihnya relatif stabil dengan jumlah penelitian berkisar dari 2-9 penelitian (2\%-9\%). Tabel 2 memperlihatkan daftar penelitian empiris dengan mail questionnaire beserta karakteristik untuk tiap-tiap penelitian yang meliputi: (1) populasi survei, (2) response rate dan ukuran sampel, (3) prosedur pre-test, (4) prosedur follow-up, (5) analisa non-response bias, dan (6) tipe ukuran dependen variabel. Karakteristik tersebut akan dianalisis dalam pembahasan beserta dengan data yang tidak ditabulasikan dalam tabel tersebut.

Tabel 2. Penelitian survei di bidang akuntansi manajemen dan keperilakuan dengan mail questionnaire

\begin{tabular}{|c|c|c|c|c|c|c|c|c|c|}
\hline No. & Pengarang & SNA & Tahun & $\begin{array}{c}\text { Sampel } \\
\text { (misal: } 50 \text { manajer } \\
\text { akumtansi perusahaan } \\
\text { BEI) }\end{array}$ & $\begin{array}{c}\text { Response Rate } \\
\text { (misal: } 97 / 154=63 \% \text { ) }\end{array}$ & $\begin{array}{c}\text { Instrumen } \\
\text { Pretest } \\
\text { (yes/no) }\end{array}$ & $\begin{array}{l}\text { Prosedur } \\
\text { Follow up } \\
\text { (yes/no) }\end{array}$ & $\begin{array}{l}\text { Analisis } \\
\text { Non- } \\
\text { Response } \\
\text { (yes/no) }\end{array}$ & $\begin{array}{c}\text { Tipe variabel } \\
\text { dependen }\end{array}$ \\
\hline 1 & $\begin{array}{l}\text { Taniel, Ika Susana } \\
\text { dan Hekinus } \\
\text { Manao }\end{array}$ & 2 & 1999 & $\begin{array}{l}150 \text { karyawan perusahaan } \\
\text { jasa di Jakarta }\end{array}$ & $43 / 150=29 \%$ & N/A & N/A & N/A & self rating \\
\hline 2 & $\begin{array}{l}\text { Restuningdiah, } \\
\text { Nurika dan Nur } \\
\text { Indriantoro }\end{array}$ & 2 & 1999 & $\begin{array}{l}1000 \text { kuesioner untuk } 250 \\
\text { perusahaan }\end{array}$ & $\begin{array}{l}137,102 / 1000= \\
13,7 \% ; 10,2 \%\end{array}$ & N/A & N/A & No & self rating \\
\hline 3 & $\begin{array}{l}\text { Kamal, Maulana } \\
\text { dan Ainun Na'im }\end{array}$ & 2 & 1999 & $\begin{array}{l}465 \text { kuesioner untuk } \\
\text { manajer dan staf } \\
\text { perusahaan manufaktur }\end{array}$ & $\begin{array}{l}99,89 / 465=21,29 \% \\
19,14 \%\end{array}$ & N/A & Yes & N/A & self rating \\
\hline 4 & Riyadi, Slamet & 2 & 1999 & $\begin{array}{l}340 \text { manajer perusahaan } \\
\text { manufaktur di Jatim }\end{array}$ & $\begin{array}{l}62,48 / 340=18,24 \% \\
14,19 \%\end{array}$ & N/A & N/A & Yes & self rating \\
\hline 5 & $\begin{array}{l}\text { Sih Wahyuni dan } \\
\text { Gudono }\end{array}$ & 2 & 1999 & 500 akuntan & $151 / 500=30,2 \%$ & Yes & N/A & N/A & self rating \\
\hline 6 & $\begin{array}{l}\text { Laksmi, Ayu } \\
\text { Chairina dan Nur } \\
\text { Indriantoro }\end{array}$ & 2 & 1999 & $\begin{array}{l}520 \text { aktn publik di KAP } \\
\text { Jakarta }\end{array}$ & $\begin{array}{l}158,146 / 520= \\
30,39 \% ; 28,08 \%\end{array}$ & N/A & N/A & N/A & self report \\
\hline 7 & $\begin{array}{l}\text { Nurahma, Myrna } \\
\text { dan Nur } \\
\text { indriantoro }\end{array}$ & 2 & 1999 & 520 KAP di Jakarta & $\begin{array}{l}120,97 / 520= \\
23,08 \% ; 18,65 \%\end{array}$ & N/A & N/A & N/A & self rating \\
\hline 8 & Nurkholis & 2 & 1999 & $\begin{array}{l}300 \text { manajer akuntansi dan } \\
\text { akuntan publik di Australia }\end{array}$ & $150 / 300=50 \%$ & Yes & Yes & N/A & self report \\
\hline 9 & Muawanah, Umi & 3 & 2000 & $\begin{array}{l}300 \text { auditor KAP di } \\
\text { Indonesia }\end{array}$ & $\begin{array}{l}91,75 / 300=30,33 \% \\
25 \%\end{array}$ & N/A & Yes & Yes & self rating \\
\hline 10 & Lindrianasari & 3 & 2000 & $\begin{array}{l}600 \text { pengguna komputer di } \\
\text { berbagai sektor perusahaan }\end{array}$ & $\begin{array}{l}135,109 / 600= \\
22,5 \% ; 18,17 \%\end{array}$ & N/A & N/A & N/A & self report \\
\hline 11 & $\begin{array}{l}\text { Putra, Eka } \\
\text { Priastana dan } \\
\text { Ainun Naim }\end{array}$ & 3 & 2000 & $\begin{array}{l}200 \text { manajer di seminar } \\
\text { Asosiasi Manajer Indonesia, } \\
\text { dikirim lagi } 88 \text { kuesioner }\end{array}$ & $\begin{array}{l}52,36 / 200=26 \% \\
18 \%\end{array}$ & Yes & Yes & N/A & self report \\
\hline 12 & $\begin{array}{l}\text { Kurnianingsih, } \\
\text { Retno }\end{array}$ & 3 & 2000 & $\begin{array}{l}500 \text { kuesioner untuk } 100 \\
\text { perusahaan manufaktur di } \\
\text { BEJ }\end{array}$ & $\begin{array}{l}53,47 / 500=10,6 \% \\
9,4 \%\end{array}$ & No & N/A & No & self rating \\
\hline 13 & $\begin{array}{l}\text { Mardiyah, Aida } \\
\text { Ainul dan Gudono }\end{array}$ & 3 & 2000 & $\begin{array}{l}720 \text { manajer pemasaran } \\
\text { dan produksi dari ICMD '98 }\end{array}$ & $\begin{array}{c}120,66 / 720= \\
16,67 \% ; 9,17 \%\end{array}$ & Yes & N/A & N/A & self report \\
\hline
\end{tabular}




\begin{tabular}{|c|c|c|c|c|c|c|c|c|c|}
\hline 14 & Adli & 4 & 2001 & $\begin{array}{l}408 \text { manajer dari Pusat } \\
\text { Data Bisnis Indonesia }\end{array}$ & $\begin{array}{l}62,58 / 408=15,2 \% \\
14,22 \%\end{array}$ & Yes & Yes & Yes & self rating \\
\hline 15 & $\begin{array}{l}\text { Prasetyo, Priyono } \\
\text { Puji }\end{array}$ & 4 & 2001 & $\begin{array}{l}300 \text { manajer perusahaan } \\
\text { manufaktur di BEJ }\end{array}$ & $\begin{array}{l}57,45 / 300=19 \% \\
15 \%\end{array}$ & Yes & N/A & Yes & self report \\
\hline 16 & Faisal & 4 & 2001 & 388 manajer $\mathrm{R} \& \mathrm{D}$ & $\begin{array}{l}86,57 / 388=22,17 \% \\
14,7 \%\end{array}$ & N/A & N/A & Yes & self rating \\
\hline 17 & Hudayati, Ataina & 4 & 2001 & $\begin{array}{l}318 \text { PD II di PTN/S, Institut } \\
\text { N/S seIndonesia }\end{array}$ & $\begin{array}{l}102,84 / 318= \\
32,08 \% ; 26,42 \%\end{array}$ & N/A & N/A & Yes & self rating \\
\hline 18 & Murtiyani, Siti & 4 & 2001 & $\begin{array}{l}150 \text { manajer (Dekan, } \\
\text { Pembantu Dekan, dll) PTS } \\
\text { di Jogja }\end{array}$ & $\begin{array}{l}52,42 / 150=34,67 \% \\
28 \%\end{array}$ & N/A & N/A & N/A & self rating \\
\hline 19 & Darlis, Edfan & 4 & 2001 & $\begin{array}{l}120 \text { manajer perusahaan } \\
\text { manufaktur di BEJ dengan } \\
3 \text { kuesioner/@ }\end{array}$ & $57,54 / 360$ & N/A & N/A & N/A & self rating \\
\hline 20 & $\begin{array}{l}\text { Fredianto, Ronie } \\
\text { dan Zulaikha }\end{array}$ & 4 & 2001 & $\begin{array}{l}200 \text { prshn manufaktur } \\
\text { menengah-kecil di SMG }\end{array}$ & $90 / 200=45 \%$ & N/A & N/A & N/A & data keuangn \\
\hline 21 & $\begin{array}{l}\text { Alim, Mohammad } \\
\text { Nizarul }\end{array}$ & 5 & 2002 & $\begin{array}{l}200 \text { manajer pemasaran } \\
\text { manufaktur }\end{array}$ & $\begin{array}{l}59,56 / 200=29,5 \% \\
28 \%\end{array}$ & N/A & Yes & N/A & self rating \\
\hline 22 & $\begin{array}{l}\text { Rahman, Firdaus } \\
\text { Abdul }\end{array}$ & 5 & 2002 & $\begin{array}{l}100 \text { perusahaan } \\
\text { manufaktur di Batam, } \\
\text { @3kuesioner }\end{array}$ & $\begin{array}{l}76,71 / 300=25,33 \% \\
23,67 \%\end{array}$ & N/A & N/A & N/A & self rating \\
\hline 23 & $\begin{array}{l}\text { Poerwanti, } \\
\text { Tjahjaning }\end{array}$ & 5 & 2002 & $\begin{array}{l}700 \text { manajer perusahaan } \\
\text { manufaktur BEJ } 2000\end{array}$ & $\begin{array}{l}83,77 / 700=11,86 \% \\
11 \%\end{array}$ & No & N/A & Yes & self rating \\
\hline 24 & $\begin{array}{l}\text { Arifuddin, Sri } \\
\text { Anik, dan Yusni } \\
\text { Wahyudin }\end{array}$ & 5 & 2002 & NA & $\mathrm{NA}$ & N/A & N/A & N/A & self rating \\
\hline 25 & $\begin{array}{l}\text { Tjakrawala, F.X } \\
\text { Kurniawan }\end{array}$ & 5 & 2002 & $\begin{array}{l}300 \text { eksekutif puncak } \\
\text { perusahaan manufaktur di } \\
\text { BEJ } 2000\end{array}$ & $\begin{array}{l}83,74 / 300=27,67 \% \\
24,67 \%\end{array}$ & Yes & Yes & Yes & self report \\
\hline 26 & $\begin{array}{l}\text { Hariyanti, Widi } \\
\text { dan Mohamad } \\
\text { Nasir }\end{array}$ & 5 & 2002 & $\begin{array}{l}900 \text { manajer perusahaan } \\
\text { manufaktur di Indonesia }\end{array}$ & $\begin{array}{l}139,135 / 900= \\
15,44 \% ; 15 \%\end{array}$ & N/A & N/A & Yes & self rating \\
\hline 27 & Muslichah & 5 & 2002 & $\begin{array}{l}150 \text { manajer perusahaan } \\
\text { manufaktur di Jatim }\end{array}$ & $118 / 150=78,67 \%$ & N/A & Yes & N/A & self rating \\
\hline 28 & $\begin{array}{l}\text { Rasuli, M. dan } \\
\text { Hadori Yunus }\end{array}$ & 5 & 2002 & $\begin{array}{l}596 \text { manajer menengah } \\
\text { BUMN Indonesia }\end{array}$ & $\begin{array}{l}168,155 / 596= \\
28,19 \% ; 26 \%\end{array}$ & N/A & Yes & Yes & self report \\
\hline 29 & Rusmana, Oman & 6 & 2003 & $\begin{array}{l}307 \text { perusahaan yang } \\
\text { mengikuti PROKASIH dari } \\
\text { BAPEDAL }\end{array}$ & $65,61 / 307=19,87 \%$ & N/A & N/A & Yes & self rating \\
\hline 30 & $\begin{array}{l}\text { Supriyono, R.A. } \\
\text { dan Akhmad } \\
\text { Syakhroza }\end{array}$ & 6 & 2003 & $\begin{array}{l}293 \text { Dirut di capital market } \\
\text { directory }=2930 \text { kuesioner }\end{array}$ & $\begin{array}{l}350,341 / 2930= \\
11,64 \%\end{array}$ & N/A & N/A & Yes & self rating \\
\hline 31 & Halimatusyadiah & 6 & 2003 & 550 auditor KAP di Jawa & $\begin{array}{l}126,111 / 550= \\
20,18 \%\end{array}$ & N/A & N/A & N/A & self report \\
\hline 32 & $\begin{array}{l}\text { Lekatompessy, } \\
\text { Jantje Eduard dan } \\
\text { Anis Chariri }\end{array}$ & 6 & 2003 & $\begin{array}{l}517 \text { akuntan KAP dan } \\
\text { industri di Jakarta, } \\
\text { Surabaya, Bandung, } \\
\text { Semarang }\end{array}$ & $\begin{array}{l}323,278 / 517= \\
53,77 \%\end{array}$ & N/A & N/A & N/A & self rating \\
\hline 33 & $\begin{array}{l}\text { Maksum, Azhar } \\
\text { dan Azizul Kholis }\end{array}$ & 6 & 2003 & 300 perusahaan di Medan & $67,54 / 300=18 \%$ & N/A & Yes & No & self report \\
\hline 34 & $\begin{array}{l}\text { Budiwibowo, } \\
\text { Triyono dan Arfan } \\
\text { Ikhsan }\end{array}$ & 6 & 2003 & $\begin{array}{l}850 \text { perusahaan dari } \mathrm{PT} \\
\text { Kompassindo dan ICMD }\end{array}$ & $236 / 850=29 \%$ & N/A & N/A & N/A & self report \\
\hline 35 & Rahim, Syamsuri & 6 & 2003 & $\begin{array}{l}281 \text { perusahaan di BEJ dan } \\
\text { ICMD }\end{array}$ & $46,42 / 281=14,95 \%$ & N/A & N/A & N/A & self report \\
\hline 36 & $\begin{array}{l}\text { Suprantiningrum } \\
\text { dan Zulaikha }\end{array}$ & 6 & 2003 & 465 manajer perusahaan & $85,79 / 465=17 \%$ & Yes & N/A & Yes & self rating \\
\hline 37 & Lesmana, Sukma & 6 & 2003 & $\begin{array}{l}156 \text { perusahaan farmasi } \\
\text { yang diterbitkan } \\
\text { Kompassindo }\end{array}$ & $67 / 156=36,02 \%$ & Yes & Yes & N/A & self rating \\
\hline 38 & Musyarofah, Siti & 6 & 2003 & $\begin{array}{l}\text { GM atau manajer } \\
\text { menengah perusahaan } \\
\text { manufaktur yg diterbitkan } \\
\text { Kompassindo }\end{array}$ & - & N/A & N/A & N/A & self rating \\
\hline 39 & $\begin{array}{l}\text { Lau, Elfreda } \\
\text { Aplonia }\end{array}$ & 6 & 2003 & $\begin{array}{l}600 \text { kuesioner untuk } 120 \\
\text { perusahaan di NTT }\end{array}$ & $\begin{array}{l}122,100 / 600= \\
16,67 \%\end{array}$ & N/A & N/A & N/A & self rating \\
\hline 40 & Diana, Nur & 6 & 2003 & $\begin{array}{l}400 \text { manager BUMN } \\
\text { seIndonesia }\end{array}$ & $151,140 / 400=35 \%$ & Yes & N/A & N/A & self rating \\
\hline 41 & Wahyudin, M. & 6 & 2003 & $\begin{array}{l}750 \text { akuntan, mahasiswa di } \\
\text { Jawa }\end{array}$ & $\begin{array}{l}222,206 / 750= \\
27,47 \%\end{array}$ & Yes & N/A & N/A & self rating \\
\hline 42 & $\begin{array}{l}\text { Limantara, Feny } \\
\text { dan Devie }\end{array}$ & 6 & 2003 & 217 perbankan & $30 / 217=13,82 \%$ & N/A & N/A & N/A & self rating \\
\hline
\end{tabular}




\begin{tabular}{|c|c|c|c|c|c|c|c|c|c|}
\hline & $\begin{array}{l}\text { Naim, Ainun, } \\
\text { Chong M. Lau dan }\end{array}$ & 6 & 2003 & $\begin{array}{l}229 \text { manajer manufaktur di } \\
\text { BEJ }\end{array}$ & $83,70 / 229=30,57 \%$ & N/A & Yes & N/A & self rating \\
\hline 44 & $\begin{array}{l}\text { Suryaningrum, } \\
\text { Diah Hari }\end{array}$ & 6 & 2003 & $\begin{array}{l}389 \text { kuesioner untuk } 125 \\
\text { BUMN }\end{array}$ & $58,49 / 389=12,6 \%$ & N/A & N/A & N/A & self rating \\
\hline 45 & Amrul, Sadat & 7 & 2004 & $\begin{array}{l}500 \text { bank umum di } \\
\text { Indonesia }\end{array}$ & $95,92 / 500=18,4 \%$ & N/A & N/A & N/A & self rating \\
\hline 46 & $\begin{array}{l}\text { Latuheru, } \\
\text { Belianus Patria } \\
\text { dan Arifin Sabeni }\end{array}$ & 7 & 2004 & $\begin{array}{l}616 \text { PD II Universitas dan } \\
\text { Institut }\end{array}$ & $103,97 / 616=15,75 \%$ & N/A & N/A & N/A & self rating \\
\hline 47 & $\begin{array}{l}\text { Purnamasari, } \\
\text { Dian Indri dan } \\
\text { Indra Wijaya } \\
\text { Kusuma }\end{array}$ & 7 & 2004 & $\begin{array}{l}593 \text { perusahaan di } \\
\text { Handbook of the top } \\
\text { companies and big grup }\end{array}$ & $113 / 593=19 \%$ & Yes & N/A & Yes & self report \\
\hline 48 & Jaya, Rizal & 7 & 2004 & $\begin{array}{l}161 \text { mahasiswa akuntansi } \\
\text { muslim di Jogyakarta }\end{array}$ & $87 / 161=54 \%$ & N/A & Yes & N/A & self report \\
\hline 49 & $\begin{array}{l}\text { Aisyah, Mimin } \\
\text { Nur dan Mahfud } \\
\text { Sholihin }\end{array}$ & 7 & 2004 & $\begin{array}{l}229 \text { manajer manufaktur } \\
\text { di BEJ }\end{array}$ & $83,76 / 229=33,19 \%$ & N/A & Yes & Yes & self rating \\
\hline 50 & $\begin{array}{l}\text { Solihin, Mahfud } \\
\text { dan Siti Fathonah }\end{array}$ & 7 & 2004 & $\begin{array}{l}229 \text { manajer manufaktur } \\
\text { di BEJ }\end{array}$ & $83,70 / 229=30,57 \%$ & N/A & Yes & Yes & self report \\
\hline 51 & $\begin{array}{l}\text { Fuad dan Arifin } \\
\text { Sabeni }\end{array}$ & 7 & 2004 & $\begin{array}{l}500 \text { kuesioner } \mathrm{u} / 246 \\
\text { perusahaan anak }\end{array}$ & $56 / 500=11,2 \%$ & Yes & N/A & N/A & self report \\
\hline 52 & $\begin{array}{l}\text { Amrul, Sadat dan } \\
\text { Ahyadi Syar'ie }\end{array}$ & 8 & 2005 & $\begin{array}{l}259 \text { kuesioner untuk } 24 \\
\text { bak di Statistik Bank } \\
\text { Indonesia }\end{array}$ & $93,86 / 259=33,2 \%$ & N/A & N/A & No & self rating \\
\hline 53 & $\begin{array}{l}\text { Budiyanto, Enjang } \\
\text { Tachyan, } \\
\text { Mohammad Nasir } \\
\text { dan Indira } \\
\text { Januarti }\end{array}$ & 8 & 2005 & 324 anggota IAI-KAM & $62,60 / 324=18,52 \%$ & N/A & N/A & Yes & self rating \\
\hline 54 & $\begin{array}{l}\text { Mardiyah, Aida } \\
\text { Ainul dan } \\
\text { Listianingsih }\end{array}$ & 8 & 2005 & $\begin{array}{l}150 \text { manajer tingkat } \\
\text { menengah dan pemasaran } \\
\text { di Indonesia }\end{array}$ & $24,22 / 150=14,67 \%$ & Yes & N/A & N/A & self rating \\
\hline 55 & Cahyono, Dwi & 8 & 2005 & $\begin{array}{l}500 \text { auditor KAP di } \\
\text { Indonesia }\end{array}$ & $115,110 / 500=22 \%$ & N/A & N/A & N/A & self report \\
\hline 56 & $\begin{array}{l}\text { Yusfaningrum, } \\
\text { Kusnasriyanti dan } \\
\text { Imam Ghozali }\end{array}$ & 8 & 2005 & $\begin{array}{l}700 \text { kuesioner untuk } 140 \\
\text { perusahaan manufaktur di } \\
\text { BEJ }\end{array}$ & $173,168 / 700=24 \%$ & N/A & N/A & N/A & self rating \\
\hline 57 & $\begin{array}{l}\text { Ikhsan, Arfan dan } \\
\text { Rasdianto }\end{array}$ & 8 & 2005 & $\begin{array}{l}157 \text { manajer produksi } \\
\text { manufaktur }\end{array}$ & $26 / 167=22,9 \%$ & N/A & N/A & N/A & self report \\
\hline 58 & $\begin{array}{l}\text { Astuti, Partiwi } \\
\text { Dwi dan Arifin } \\
\text { Sabeni }\end{array}$ & 8 & 2005 & $\begin{array}{l}500 \text { perusahaan terdaftar } \\
\text { di BKPMD }\end{array}$ & $162 / 500=32,4 \%$ & N/A & N/A & N/A & self report \\
\hline 59 & $\begin{array}{l}\text { Mulia, Teodora } \\
\text { Winda dan Indra } \\
\text { Wijaya Kusuma }\end{array}$ & 8 & 2005 & $\begin{array}{l}450 \text { kuesioner untuk KAP } \\
\text { di Jawa }\end{array}$ & $139 / 450=30,89 \%$ & N/A & N/A & Yes & self rating \\
\hline 60 & $\begin{array}{l}\text { Sunarta, I } \\
\text { Nyoman dan } \\
\text { Partiwi Dwi Astuti }\end{array}$ & 8 & 2005 & $\begin{array}{l}500 \text { staf akuntansi di } \\
\text { semua hotel di Badung,Bali }\end{array}$ & $172,163 / 500=32,6 \%$ & N/A & N/A & N/A & self report \\
\hline 61 & Raharja, Surya & 8 & 2005 & $\begin{array}{l}500 \text { kantor perwakilan } \\
\text { BPK }\end{array}$ & $134,122 / 500=24,4 \%$ & Yes & N/A & N/A & $\begin{array}{c}\text { dummy } \\
\text { variabel } \\
\text { (mengguna- } \\
\text { kan/tidak) }\end{array}$ \\
\hline 62 & Komara, Acep & 8 & 2005 & $\begin{array}{l}333 \text { perusahaan di } \\
\text { Direktori Industri BPS }\end{array}$ & $83 / 333=24,92 \%$ & N/A & N/A & N/A & self rating \\
\hline 63 & $\begin{array}{l}\text { Aziza, Nurna, } \mathrm{H} \text {. } \\
\text { Mohamad Nasir } \\
\text { dan Daljono }\end{array}$ & 9 & 2006 & 613 auditor KAP se-Jawa & $86,63 / 613=10,28 \%$ & N/A & N/A & N/A & ukuran jam \\
\hline 64 & $\begin{array}{l}\text { Ratmono, Dwi dan } \\
\text { Yogi Hendro } \\
\text { Prabowo }\end{array}$ & 9 & 2006 & $\begin{array}{l}250 \text { klien KAP di Solo, } \\
\text { SMG, JKT }\end{array}$ & $110,105 / 250=42 \%$ & N/A & N/A & N/A & self report \\
\hline 65 & $\begin{array}{l}\text { Mulyaningsih, } \\
\text { Nining dan } \\
\text { Enjang Tachyan } \\
\text { budiyanto }\end{array}$ & 9 & 2006 & 300 anggota IAI-KAM & $65 / 300=21,67 \%$ & N/A & N/A & N/A & self report \\
\hline 66 & $\begin{array}{l}\text { Wahyudi, Hendro } \\
\text { dan Aida Ainul } \\
\text { Mardiyah }\end{array}$ & 9 & 2006 & $\begin{array}{l}30 \text { staf KAP Suprihadi } \\
\text { dan rekan di Malang }\end{array}$ & $30 / 30=100 \%$ & N/A & N/A & Yes & self report \\
\hline 67 & Yuningsih & 9 & 2006 & $\begin{array}{l}211 \text { manajer menengah } \\
\text { di } 3 \text { perusahaan multi- } \\
\text { nasional }\end{array}$ & $81,69 / 211=32,7 \%$ & Yes & N/A & N/A & self rating \\
\hline
\end{tabular}




\begin{tabular}{|c|c|c|c|c|c|c|c|c|c|}
\hline 68 & $\begin{array}{l}\text { Mustikawati, } \mathrm{Rr} \\
\text { Indah }\end{array}$ & 9 & 2006 & $\begin{array}{l}750 \text { akuntan manajemen di } \\
\text { Hand Book o the Top } \\
\text { Companies }\end{array}$ & $\begin{array}{l}121,110 / 750= \\
14,67 \%\end{array}$ & N/A & N/A & N/A & self rating \\
\hline 69 & Nizarudin, Abu & 9 & 2006 & $\begin{array}{l}1000 \text { manajer produksi dan } \\
\text { marketing, perusahaan } \\
\text { manufaktur di Standard } \\
\text { Trade \& Industry Directory }\end{array}$ & $\begin{array}{l}161,135 / 1000= \\
13,5 \%\end{array}$ & yes & N/A & N/A & self rating \\
\hline 70 & Kiryanto & 9 & 2006 & $\begin{array}{l}125 \text { akuntan KAP di Jateng } \\
\text { dan DIY }\end{array}$ & $67 / 125=54 \%$ & N/A & N/A & N/A & self rating \\
\hline 71 & $\begin{array}{l}\text { Iman VK, Nafie } \\
\text { dan Jogiyanto HM }\end{array}$ & 9 & 2006 & $\begin{array}{l}\text { manajer dan jajaran direksi } \\
\text { Bank }\end{array}$ & Kisaran 10\% & N/A & N/A & N/A & self rating \\
\hline 72 & $\begin{array}{l}\text { Ja'far, } \\
\text { Muhammad S. } \\
\text { dan Dista Amalia } \\
\text { Sarifah }\end{array}$ & 9 & 2006 & $\begin{array}{l}100 \text { perusahaan di BEJ } \\
\text { tahun } 2006\end{array}$ & $53 / 100=53 \%$ & N/A & N/A & No & $\begin{array}{l}\text { dummy } \\
\text { variabel (dari } \\
\text { annual report) }\end{array}$ \\
\hline 73 & Faisal & 9 & 2006 & $\begin{array}{l}800 \text { kuesioner } \mathrm{u} / \\
\text { perusahaan manufaktur di } \\
\text { BEJ }\end{array}$ & $102 / 800=12,75 \%$ & No & N/A & N/A & self rating \\
\hline 74 & $\begin{array}{l}\text { Utami, Intiyas, } \\
\text { Muchammad } \\
\text { Syafrudin dan Rr. } \\
\text { Sri Handayani }\end{array}$ & 9 & 2006 & 575 auditor & $168,157 / 575=27,3 \%$ & N/A & N/A & Yes & self rating \\
\hline 75 & $\begin{array}{l}\text { Jumaili, Salman } \\
\text { dan Gudono }\end{array}$ & 9 & 2006 & $\begin{array}{l}527 \text { manajer perusahan } \\
\text { manufaktur di Indonesia }\end{array}$ & $58 / 527=11 \%$ & N/A & N/A & N/A & self report \\
\hline 76 & $\begin{array}{l}\text { Alim, M. Nizarul, } \\
\text { Trisni Hapsari dan } \\
\text { Liliek Purwanti }\end{array}$ & 10 & 2007 & 220 auditor KAP di Jatim & $75 / 220=34,09 \%$ & N/A & Yes & N/A & \\
\hline 77 & Pratolo, Suryo & 10 & 2007 & $\begin{array}{l}\text { 59, dengan } 3 \\
\text { kuesioner/perusahaan } \\
\text { BUMN = } 177 \text { manajer, } \\
\text { komisaris, sekretaris }\end{array}$ & $? ?$ & N/A & N/A & N/A & \\
\hline 78 & $\begin{array}{l}\text { Ifada, Luluk } \\
\text { Muhimatul }\end{array}$ & 11 & 2008 & $\begin{array}{l}250 \text { manajer kancab } \\
\text { perbankan di Jateng }\end{array}$ & $104,93 / 250=37,2 \%$ & N/A & N/A & yes & self rating \\
\hline 79 & $\begin{array}{l}\text { Primasari, Dona, } \\
\text { Lego Waspodo dan } \\
\text { Syaiful Rahman }\end{array}$ & 11 & 2008 & 350 aparat pemda Jateng & $157,148 / 350=42,29 \%$ & N/A & N/A & Yes & self rating \\
\hline 80 & $\begin{array}{l}\text { Ja'far, } \\
\text { Muhammad S. } \\
\text { dan Lisa } \\
\text { Kartikasari }\end{array}$ & 11 & 2008 & 160 CEO BPR se-Jateng & $102,97 / 160=60,63 \%$ & N/A & N/A & N/A & $\begin{array}{l}\text { ukuran } \\
\text { keuangan }\end{array}$ \\
\hline 81 & $\begin{array}{l}\text { Yuvisa, Ewing I., } \\
\text { H. Abdul Rohman } \\
\text { dan Rr. Sri } \\
\text { Handayani }\end{array}$ & 11 & 2008 & $\begin{array}{l}500 \text { auditor pelaksana di } \\
\text { KAP se-Indonesia }\end{array}$ & $199 / 200=20,8 \%$ & No & N/A & N/A & self rating \\
\hline 82 & $\begin{array}{l}\text { Martiningsih, Rr. } \\
\text { Sri Pancawati }\end{array}$ & 12 & 2009 & 457 orang dari 10 provinsi & $457 / 457=100 \%$ & N/A & N/A & N/A & sel report \\
\hline 83 & $\begin{array}{l}\text { Lestari, Baiq } \\
\text { Anggun Hilendra } \\
\text { dan Susi Retna C }\end{array}$ & 12 & 2009 & $\begin{array}{l}735 \text { manajer perusahaan } \\
\text { manufaktur di BEI } 2006\end{array}$ & $158 / 735=21,50 \%$ & N/A & N/A & N/A & self rating \\
\hline 84 & $\begin{array}{l}\text { Wiryantoro, Lili } \\
\text { Sugeng, Ayu } \\
\text { Noorida Soerono, } \\
\text { Munawar Muchlis } \\
\text { dan Tubagus } \\
\text { Ismail }\end{array}$ & 12 & 2009 & $\begin{array}{l}560 \text { manajer perusahaan } \\
\text { manufaktur di Banten } \\
\text { terdaftar di BPS }\end{array}$ & $103,82 / 560=14,64 \%$ & N/A & N/A & Yes & self rating \\
\hline 85 & $\begin{array}{l}\text { Ja'far, } \\
\text { Muhammad S. } \\
\text { dan Lisa } \\
\text { Kartikasari }\end{array}$ & 12 & 2009 & $\begin{array}{l}112 \text { manajer bagian } \\
\text { produksi, internal auditor } \\
\text { dan akuntansi }\end{array}$ & $47 / 112=41,96 \%$ & N/A & N/A & N/A & \\
\hline 86 & $\begin{array}{l}\text { Ifada, Luluk } \\
\text { Muhimatul dan } \\
\text { Kiswanto }\end{array}$ & 13 & 2010 & $\begin{array}{l}250 \text { manajer kancab } \\
\text { perbankan di Jateng }\end{array}$ & $104,93 / 250=37,2 \%$ & N/A & N/A & Yes & self rating \\
\hline 87 & $\begin{array}{l}\text { Tjakrawala, F.X. } \\
\text { Kurniawan dan } \\
\text { Aldo Cahyo }\end{array}$ & 13 & 2010 & $\begin{array}{l}330 \text { end user software } \\
\text { akuntansi perusahaan di } \\
\text { BEI }\end{array}$ & $\begin{array}{l}153,127 / 330= \\
38,49 \%\end{array}$ & Yes & N/A & N/A & self rating \\
\hline 88 & $\begin{array}{l}\text { Yulianto, Agus } \\
\text { Solikhan dan Lili } \\
\text { Sugeng Wiyantoro }\end{array}$ & 13 & 2010 & $\begin{array}{l}450 \text { auditor junior KAP } \\
\text { terdaftar di IAPI }\end{array}$ & $97,81 / 450=18 \%$ & N/A & N/A & Yes & self rating \\
\hline 89 & $\begin{array}{l}\text { Manik, Suharno } \\
\text { Leonard Sabam } \\
\text { dan Muchammad } \\
\text { Syafrudin }\end{array}$ & 13 & 2010 & $\begin{array}{l}306 \text { akuntan } \\
\text { pendidik/dosen SMG, } \\
\text { Salatiga, Solo }\end{array}$ & $\begin{array}{l}160,129 / 306= \\
42,16 \%\end{array}$ & N/A & No & N/A & self rating \\
\hline
\end{tabular}




\begin{tabular}{|c|c|c|c|c|c|c|c|c|c|}
\hline 90 & $\begin{array}{l}\text { Fitriany, } \\
\text { Lindawati Gani, } \\
\text { Sylvia V.N.P.S, } \\
\text { Arywarti } \\
\text { Marganingsih dan } \\
\text { Viska Anggrahita }\end{array}$ & 13 & 2010 & 1444 auditor di KAP besar & $\begin{array}{l}1216,1178 / 1444= \\
81,6 \%\end{array}$ & Yes & N/A & N/A & self rating \\
\hline 91 & $\begin{array}{l}\text { Singgih, Elisha } \\
\text { Muliani dan Icuk } \\
\text { Rangga Bawono }\end{array}$ & 13 & 2010 & $\begin{array}{l}200 \text { auditor member "BIG } \\
\text { FOUR" }\end{array}$ & $136 / 200=68 \%$ & N/A & N/A & N/A & self rating \\
\hline 92 & $\begin{array}{l}\text { Juniarti, Indira } \\
\text { dan Faisal }\end{array}$ & 13 & 2010 & $\begin{array}{l}145 \text { BPK di Kalbar dan } \\
\text { Sulsel }\end{array}$ & $123,120 / 145=82,8 \%$ & N/A & N/A & N/A & self rating \\
\hline 93 & Yuliana, Christina & 13 & 2010 & $\begin{array}{l}223 \text { manager perusahaan } \\
\text { manufaktur di BEI }\end{array}$ & $93 / 223=41,70 \%$ & N/A & N/A & Yes & self rating \\
\hline 94 & $\begin{array}{l}\text { Purwanto, Agus } \\
\text { dan Siti Nur } \\
\text { Hadiyati }\end{array}$ & 14 & 2011 & $\begin{array}{l}750 \text { manajer RS swasta di } \\
\text { Jateng }\end{array}$ & $239 / 750=31,47 \%$ & N/A & N/A & Yes & self rating \\
\hline 95 & $\begin{array}{l}\text { Ramdhani, Budi, } \\
\text { Munawar Mukhlis } \\
\text { dan Elvin Bastian }\end{array}$ & 14 & 2011 & $\begin{array}{l}270 \text { manajer perusahaan } \\
\text { manufaktur di Banten }\end{array}$ & $\begin{array}{l}157,147 / 270= \\
54,44 \%\end{array}$ & N/A & No & Yes & self report \\
\hline 96 & $\begin{array}{l}\text { Respati, Novita } \\
\text { Weningtyas }\end{array}$ & 14 & 2011 & $\begin{array}{l}1700 \text { manajer keuangan } \\
\text { dan akuntansi perusahaan } \\
\text { manufaktur di Indonesia }\end{array}$ & $186,148 / 1700=8,7 \%$ & N/A & N/A & Yes & self report \\
\hline 97 & $\begin{array}{l}\text { Wiyantoro, Lili } \\
\text { Sugeng, Agus } \\
\text { Solikhan Yulianto, } \\
\text { Munawar Mukhlis } \\
\text { dan Dadan } \\
\text { Ramdhani }\end{array}$ & 14 & 2011 & $\begin{array}{l}644 \text { auditor, akuntan } \\
\text { pendidik }\end{array}$ & $\begin{array}{l}109,100 / 644= \\
15,53 \%\end{array}$ & N/A & N/A & No & self rating \\
\hline 98 & $\begin{array}{l}\text { Ratmono, Dwi dan } \\
\text { Ertambang } \\
\text { Nahartyo }\end{array}$ & 15 & 2012 & $\begin{array}{l}134 \text { controller, perusahaan } \\
\text { manufaktur di BEI }\end{array}$ & $49 / 134=37,12 \%$ & Yes & Yes & Yes & self rating \\
\hline 99 & $\begin{array}{l}\text { Papat, Neng, } \\
\text { Tubagus Ismail } \\
\text { dan Galih Fajar } \\
\text { M. }\end{array}$ & 15 & 2012 & $\begin{array}{l}320 \text { manajer (macam- } \\
\text { macam) perusahaan } \\
\text { manufaktur di Banten }\end{array}$ & $57 / 320=17,81 \%$ & N/A & N/A & N/A & self rating \\
\hline & $\begin{array}{l}\text { Purbandari, } \\
\text { Theresia dan } \\
\text { Mujilan }\end{array}$ & 15 & 2012 & $\begin{array}{l}1007 \text { manajer bank di } \\
\text { Jatim }\end{array}$ & $141 / 1007=14 \%$ & N/A & N/A & N/A & self report \\
\hline 101 & $\begin{array}{l}\text { Irawati, Anik dan } \\
\text { Supriyadi }\end{array}$ & 15 & 2012 & 150 pemeriksa BPK & $138 / 150=92 \%$ & NA & NA & N/A & self rating \\
\hline & $\begin{array}{l}\text { Lindrianasari, } \\
\text { Jogiyanto, } \\
\text { Supriyadi dan } \\
\text { Setiyono Miharjo }\end{array}$ & 15 & 2012 & $\begin{array}{l}458 \text { CEO perusahaan besar } \\
\text { di Indonesia }\end{array}$ & $68,61 / 458=13,32 \%$ & N/A & N/A & N/A & self rating \\
\hline & $\begin{array}{l}\text { Rimawati, Yuni } \\
\text { dan Setyo Hari } \\
\text { Wijanto }\end{array}$ & 15 & 2012 & $250 \mathrm{WP}$ & $164,154 / 250=61,6 \%$ & Yes & N/A & N/A & self rating \\
\hline 104 & $\begin{array}{l}\text { Nasution, Hafifah } \\
\text { dan Fitriany }\end{array}$ & 15 & 2012 & 250 auditor KAP di Jakarta & $87 / 250=34,8 \%$ & N/A & N/A & N/A & self rating \\
\hline 105 & Nor, Wahyudin & 15 & 2012 & $\begin{array}{l}509 \text { auditor eksternal KAP } \\
\text { terdaftar di BPK RI }\end{array}$ & $191 / 509=37,52 \%$ & N/A & N/A & N/A & self rating \\
\hline & $\begin{array}{l}\text { Tjakrawala, F.X } \\
\text { Kurniawan dan } \\
\text { Andreas Lukita }\end{array}$ & 15 & 2012 & $\begin{array}{l}525 \\
\text { supervisor,manajer,direktur } \\
\text { perusahaan manufaktur di } \\
\text { BEI }\end{array}$ & $\begin{array}{l}110,100 / 525= \\
19,05 \%\end{array}$ & N/A & N/A & N/A & self report \\
\hline
\end{tabular}

\section{Tujuan dan Rancangan Survei}

Diamond (2000) menyatakan bahwa pernyataan tujuan penelitian merupakan hal yang sangat penting dalam penelitian survei. Mail questionnaire dapat digunakan untuk dua tujuan utama penelitian yaitu deskriptif atau explanation (Pinsonneault dan Kraemer 1993; Sudman dan Blair 1999; Cooper dan Schindler 2006; Sekaran dan Boogie 2010). Penelitian dengan tujuan deskritif adalah penelitian yang dilakukan untuk menemukan karakteristik suatu populasi, sedangkan pene- litian dengan tujuan explanation adalah penelitian yang dilakukan untuk mencari hubungan (korelasi maupun causal) antara dua atau beberapa variabel atau untuk menguji suatu teori (Pinsonneault dan Kraemer 1993, Cooper dan Schindler 2006).

Dari data yang tidak ditabulasikan, terlihat bahwa hampir semua penelitian empiris yang menggunakan mail questionnaire bertujuan untuk menjelaskan suatu hubungan antar dua atau beberapa variabel, hanya satu penelitian yang juga bertujuan untuk menjelaskan karakteristik suatu populasi. Tujuan penelitian tersebut mempenga- 
ruhi perancangan metode penelitian yang digunakan, misalnya pada pilihan perancangan penelitian cross-sectional atau longitudinal, ataupun penentuan unit analisis. Penelitian longitudinal adalah penelitian yang mengharuskan peneliti untuk memperoleh data dari dua atau lebih periode waktu (Sekaran dan Bougie 2010), sehingga kalau penelitian tersebut menggunakan mail questionnaire maka peneliti harus mengirimkan survei kuesionernya beberapa kali dalam rentang waktu penelitian. Pinsonneault dan Kraemer (1993) menyatakan bahwa penelitian longitudinal menghasilkan keyakinan yang lebih besar untuk menemukan hubungan causal antara dua atau beberapa variabel dibandingkan dengan penelitian cross-sectional. Rancangan penelitian longitudinal tidak banyak digunakan untuk penelitian survei dengan mail questionnaire karena tingkat kesulitan yang relatif tinggi dan biaya yang mahal. Semua penelitian akuntansi manajemen dan keperilakuan dengan mail questionnaire yang dilakukan dalam periode pengamatan semuanya menggunakan rancangan penelitian cross-sectional.

Penentuan unit analisis juga merupakan hal yang penting terutama bagi penelitian akuntansi manajemen dan keperilakuan yang seringkali berhubungan dengan fenomena pada level industri, organisasi, unit organisasi (misal: divisi, departemen), maupun level individu (Kwok dan Sharp 1998; Lutf dan Shields 2003). Ketika sebuah survei menggunakan level analisis selain level individu, maka peneliti seharusnya mempertimbangkan untuk melakukan survei dengan multiple responden pada dalam tiap level (misal: dalam suatu organisasi). Hal ini perlu dilakukan untuk meyakinkan bahwa pendapat responden tersebut mewakili keseluruhan organisasi (Young 1996), meskipun seringkali atau tidak mungkin untuk mengkonfirmasi pendapat satu responden dengan responden yang lain dalam satu organisasi karena jaminan peneliti mengenai kerahasiaan identitas responden. Pada data yang tidak ditabulasikan, tampak bahwa terdapat 35 artikel (33\%) dalam sampel yang menggunakan unit analisis level organisasi, namun hanya ada 11 artikel (10\%) yang memperoleh datanya dari multiple responden. Sebagian besar artikel dalam sampel (81\%) menggunakan unit analisis individual.

\section{Definisi Populasi dan Sampling}

Populasi adalah keseluruhan kelompok manusia, kejadian, atau sesuatu yang menjadi ketertarikan peneliti untuk diteliti (Sekaran dan Bougie 2010). Dalam penelitian dengan mail questionnaire, populasi biasanya terdiri dari manusia (yang biasanya disebut dengan responden), meskipun ada juga yang terdiri dari organisasi. Sampel adalah bagian dari populasi yang dianalisis oleh peneliti untuk mengambil kesimpulan tentang populasi. Oleh karena itu sampel harus merupakan representasi populasi. Jika sampel penelitian merupakan sampel yang representatif atas populasi maka apa yang benar atas sampel akan benar juga bagi populasi dengan tingkat kesalahan tertentu (Sapsford 1999). Pendefinisian populasi dan pemilihan sampel merupakan hal yang penting karena menentukan validitas kesimpulan yang diambil dari sampel tersebut. Dalam mail questionnaire, validitas kesimpulan juga tergantung dari besarnya ukuran sampel dan tingkat pengembalian (response-rate) dari responden.

\section{Populasi Survei}

Seorang peneliti biasanya mengidentifikasi populasi survei berdasarkan tujuan penelitian untuk memastikan bahwa populasi tersebut secara cukup mengliput target populasi. Target populasi adalah kumpulan dari semua responden yang peneliti ingin teliti (misal: manajer produksi). Sedangkan populasi survei adalah kumpulan responden yang tersedia bagi peneliti dan yang sesungguhnya dijadikan sampel (misal: manajer produksi perusahaan manufaktur). Diamond (2000) menyatakan bahwa sangat penting untuk menekankan adanya konsistensi antara target populasi dengan populasi survei. Ketidak konsistenan antara target populasi dan populasi survei dapat mengakibatkan timbulnya bias dalam mengambil kesimpulan (Henry 1990). Sebagian besar dari artikel dalam sampel penelitian ini tidak melaporkan target populasinya sehingga kami menganggap bahwa target populasi adalah populasi survei.

Dalam Tabel 2 dilaporkan populasi survei dalam sampel kami dari keseluruhan artikel dalam bidang akuntansi manajemen dan keperilakuan yang menggunakan mail questionnaire. Menggunakan keseluruhan sampel, jumlah ratarata subyek dalam populasi survei adalah 419 dengan standar deviasi sebesar 276. Kisaran antara jumlah minimum dan maksimum cukup besar yaitu minimum 30 dan maksimum 1700, dengan median 333. Namun, data dari lima artikel dapat dianggap sebagai outlier, sehingga untuk hasil penghitungan statistik yang lebih representatif, kami menghilangkan lima artikel tersebut dan melakukan penghitungan kembali. Setelah dilakukan penghitungan kembali, rata-rata subyek dalam populasi survei adalah 378 dengan standar deviasi sebesar 200. Kisaran antara jumlah minimum dan maksimum menjadi lebih kecil yaitu minimum 30 dan maksimum 900, dengan median 322. 


\section{Sampling (Pemilihan Sampel)}

Sampling atau pemilihan sampel secara langsung berhubungan dengan kemampuan generalizability dari penemuan survei. Salah satu hal yang merupakan kelebihan mail questionnaire adalah kemampuannya untuk mengumpulkan data dari sebagian populasi yang representatif (Birnberg et al. 1990). Sedangkan manfaat utama dari mail questionnaire adalah cakupan geografi luas yang dapat diliput dalam survei (Sekaran dan Bougie 2010). Namun demikian, seberapa besar manfaat tersebut dapat dicapai tergantung pada kualitas prosedur pemilihan sampelnya (sampling).

Fokus utama dalam proses pemilihan sampel (sampling procedure) adalah menentukan apakah akan menggunakan probability atau non-probability sampling. Probability sampling adalah proses pemilihan sampel dengan menganggap bahwa semua elemen populasi mempunyai kesempatan yang sama untuk terpilih menjadi subyek dalam sampel. Sedangkan dalam non-probability sampling, beberapa elemen populasi mempunyai kesempatan yang lebih besar untuk terpilih menjadi subyek sampel daripada elemen populasi yang lain (Sekaran dan Bougie 2010). Dalam legal framework, data dari survei yang menggunakan non-probability sampling dapat diakui sebagai bukti jika metode untuk memilih sampel tersebut dapat dibenarkan (justifiable) dan perhatian khusus telah dilakukan untuk mengurangi bias sampel (Diamond 2000; Morgan 1990).

Dalam akuntansi manajemen dan keperilakuan, seringkali peneliti dengan menggunakan survei tidak mempunyai sampling frame (yaitu daftar lengkap dari elemen survei populasi yang sesuai dengan target populasi yang diinginkan) sehingga dapat merencanakan pemilihan sampel dengan prosedur probability sampling. Sebagian besar artikel dalam sampel kami tidak membahas dan melaporkan rencana sampling dengan detail dan semuanya mengirimkan questionnaire ke semua elemen survei populasi. Hampir semua artikel dalam sampel menggunakan purposive sampling dan convenience sampling method yang merupakan non-probability sampling, dengan mengemukakan kriteria sampel beserta alasannya. Namun demikian, ada beberapa artikel yang melaporkan detail prosedur pemilihan sampelnya. Misalnya, Lesmana (2003) menggunakan Standard Trade and Industry Directory tahun 2000 yang diterbitkan oleh PT. Kompass Indonesia untuk menyusun sampling frame berupa perusahaan farmasi di Indonesia dan merancang probability-sampling untuk memilih sampel secara acak.

\section{Ukuran Sampel}

Suatu sampel yang reliable dan valid akan memampukan kita untuk menggeneralisir hasil dari sampel tersebut ke populasi yang kita teliti. Kemampuan untuk menggeneralisir hasil penelitian tersebut berhubungan dengan prosedur pemilihan sampel (sampling) dan ukuran sampel. Ada dua hal yang selalu dibicarakan ketika menentukan berapa ukuran sampel yang tepat, yaitu masalah ketepatan (precision) dan keyakinan (confidence) kita dalam membuat generalisasi hasil dari sampel ke populasi yang kita teliti (Sekaran dan Bougie 2010). Dalam menentukan ukuran sampel, peneliti perlu menentukan seberapa besar tingkat ketepatan (precision) yang diperlukan dengan tingkat keyakinan tertentu (confidence interval), yang mengharuskan peneliti mengestimasikan sample variance (s) maupun mengestimasikan response-rate yang diharapkan. Tetapi, Fowler (1984) menyatakan bahwa pendekatan tersebut meskipun benar namun tidak realistis dengan beberapa alasan sebagai berikut.

Pertama, sebagian besar penelitian survei bidang akuntansi manajemen dan keperilakuan mempunyai tujuan explanation (teori testing). Dalam data yang tidak ditabulasikan, terlihat bahwa hampir seluruh artikel (99\%) dalam sampel penelitian bertujuan untuk teori testing, bukan untuk mengukur mean suatu variabel dalam sampel dan menggeneralisir hasilnya ke populasi. Kedua, survei dalam bidang akuntansi manajemen dan keperilakuan mencoba untuk memperoleh informasi sebanyak-banyaknya dari responden mengenai beberapa variabel untuk keperluan menguji hubungan antar variabel tersebut. Sehingga survei dalam akuntansi manajemen dan keperilakuan biasanya dirancang untuk membuat estimasi mengenai hubungan antar beberapa variabel yang seringkali tidak memungkinkan untuk memperoleh tingkat precision yang diinginkan. Lebih lanjut, penelitian terdahulu menunjukkan bahwa non-sampling error (yaitu error yang disebabkan karena non-response dan masalah pengukuran yang tidak berhubungan dengan proses sampling) merupakan kontributor utama dari total error dalam survei (Assael dan Keon 1982), jadi bukan merupakan masalah ukuran sampel. Dari pembahasan tersebut, dapat disimpulkan bahwa ukuran sampel bukanlah merupakan hal yang utama yang menentukan kualitas data survei. Fokus utama perhatian peneliti seharusnya lebih dititikberatkan pada keberadaan non-response bias. Meskipun demikian, untuk mencapai tingkat face validity tertentu diperlukan minimum sampel sekitar 200-300 responden (Morgan 1990). Namun, dalam hal ukuran sampel 
minimum ini belum ada kesepakatan diantara para peneliti.

Tabel 2 menyajikan ukuran sampel dari 106 artikel dalam bidang akuntansi manajemen dan keperilakuan dalam sampel penelitian kami. Tabel 2 memperlihatkan bahwa hanya ada tujuh artikel (7\%) mempunyai ukuran sampel lebih besar dari 200 yang merupakan batas bawah minimum dari suatu ukuran sampel. Mean ukuran sampel dari Tabel 2 tersebut adalah 116 dengan standar deviasi 124. Tetapi, kisaran ukuran sampel tersebut memperlihatkan jarak yang sangat lebar dengan ukuran sampel terkecil 22 dan ukuran sampel terbesar 1178. Median ukuran sampel tersebut adalah 93. Namun demikian, dari 17 artikel dalam Tabel 2 dengan ukuran sampel yang lebih besar dari 150, 12 artikel mempunyai response-rate kurang dari 50\%. Hal ini menyebabkan response bias merupakan ancaman yang lebih besar daripada ukuran sampel itu sendiri.

\section{Pertanyaan Survei dan Masalah-Masalah Metode Riset yang lain}

Pembahasan yang sudah dilakukan di atas berhubungan dengan populasi (external) validity, yaitu seberapa besar penelitian survei mampu menyediakan representasi yang akurat dari populasi yang seharusnya direpresentasikan (Sapsford 1999) dan kemungkinan error yang dihadapi ketika sampel bukan merupakan representasi yang baik dari suatu populasi karena adanya kesalahan dalam melakukan pemilihan sampel (sampling error). External validity merupakan hal yang paling penting bagi penelitian survei dengan tujuan deskriptif karena penelitian tersebut bertujuan untuk menyediakan estimasi yang akurat bagi parameter populasi. Tetapi untuk penelitian survei dengan tujuan teori testing (explanation), internal validity (yaitu penentuan bahwa variasi dalam dependen variabel berhubungan dengan variasi dalam independen variabel) juga merupakan hal yang penting (Sekaran dan Bougie 2010; Cooper dan Schindler 2008). Karena hampir semua penelitian survei dalam akuntansi manajemen dan keperilakuan bertujuan teori testing (explanation) yaitu 105 (99\%) dari total artikel dalam sampel kami, maka di bagian ini akan dibahas mengenai internal validity dan hubungannya dengan error (non-sampling error). Seperti yang sudah dinyatakan oleh Assael dan Keon (1982) bahwa non-sampling error tidak kalah pentingnya dengan sampling error karena ternyata non-sampling error merupakan kontributor terbesar dalam total error suatu survei.

Non-sampling error terdiri dari dua komponen (Van der Stede et al. 2005). Komponen pertama adalah non-response error yang terjadi karena beberapa target responden tidak memberikan response. Hal ini dapat menyebabkan kemungkinan response menjadi unreliable representative dari sampel yang dipilih. Komponen kedua adalah response error, terjadi ketika beberapa responden sesungguhnya memberikan response yang tidak akurat. Response error termasuk, tetapi tidak terbatas pada, validitas pengukuran (construct validity). Apabila pertanyaan dalam survei dirancang dengan tidak baik, maka hal ini dapat mengakibatkan responden salah dalam memberikan response karena tidak memahami pertanyaan survei dengan baik yang pada akhirnya mengancam internal validity (Diamond 2000). Oleh karena itu, maka sangat penting bagi peneliti untuk merancang pertanyaan dengan baik, bagaimana penyusunan kalimatnya, bagaimana format response dirancang, bagaimana urutan pertanyaannya, dan bagaimana pertanyaan tersebut disajikan (Van der Stede et al. 2005, Dillman 2007, Sekaran dan Bougie 2010). Validitas pengukuran secara detail tidak akan dibahas dalam paper ini. Pembahasan akan lebih difokuskan pada pre-testing survei kuestioner (untuk membatasi response error), prosedur follow-up (untuk meningkatkan response rate sehingga mengurangi non-response error) dan analisis non-response bias. Selain hal tersebut, kami juga akan membahas mengenai masalah pilihan tipe ukuran dependen variabel dalam penelitian akuntansi manajemen dan keperilakuan.

\section{Pre-testing}

Salah satu kelebihan dari mail questionnaire adalah kemampuannya untuk menjangkau responden dalam area geografis yang luas. Namun demikian, metode ini juga mengandung kelemahan yaitu salah satunya adalah ketidakmampuan responden untuk mengklarifikasi pertanyaan dalam survei kepada peneliti. Hal ini dapat menyebabkan jawaban responden menjadi salah karena tidak memahami dengan baik pertanyaan dalam survei yang berakibat meningkatkan response error, atau responden menjadi malas atau enggan untuk menjawab pertanyaan survei yang berakibat naiknya non-response error. Oleh karena itu, sangat penting bagi peneliti untuk selalu meyakinkan bahwa pertanyaan survei sudah dirancang dengan baik sehingga dapat dipahami dengan baik oleh responden. Salah satu cara yang paling penting bagi peneliti untuk memperoleh keyakinan tersebut adalah dengan melakukan pretest pertanyaan-pertanyaan survei (instrument survey) (Diamond 2000, Sekaran dan Bougie 2010, Dillman 2007). Pre-test terutama sangat penting 
bagi penelitian survei dengan mail questionnaire karena responden tidak dapat melaporkan atau mengklarifikasi adanya masalah dalam pertanyaan (instrument) survei kepada peneliti. Karena pentingnya pre-test tersebut, legal standarpun juga menyarankan bahwa pre-test pertanyaan survei harus selalu dilakukan untuk menguji apakah pertanyaan (instrument) survei tersebut dapat dipahami dengan benar oleh responden dan dapat dijawab dengan mudah (Morgan 1990). Tujuan utama dari pre-test adalah untuk menguji baik pertanyaan survei (question) maupun survei (questionnaire) itu sendiri (Dillman 2007). Dillman (2007) menyarankan untuk melakukan pre-test questionnaire kepada tiga kelompok orang, yaitu: kolega, calon responden, dan para pengguna data dengan penjelasan sebagai berikut.

Pertama, kolega adalah sekelompok orang yang mempunyai pemahaman terhadap rancangan dan topik penelitian yang ingin diteliti oleh peneliti. Kolega perlu dilibatkan dalam pre-test terutama untuk menguji construct validity dari tiap item pertanyaan dan kesesuaiannya dengan tujuan penelitian. Kedua, sejumlah calon responden juga harus dilibatkan dalam pre-test untuk mencoba mengisi survei questionnaire baik di depan peneliti ataupun tanpa kehadiran peneliti untuk mengidentifikasi adanya masalah baik dalam pertanyaan maupun dalam survei questionnaire. Ketiga, pengguna data juga seharusnya dilibatkan dalam pre-test untuk memperoleh feedback dari orang-orang yang mempunyai substansi pengetahuan tentang topik penelitian survei. Young (1996) juga menyatakan bahwa melakukan pre-test kepada calon responden dan pengguna data memberikan manfaat meningkatkan kemungkinan survei menggunakan terminologi yang sesuai dengan pengetahuan responden sehingga menurunkan keengganan calon responden untuk berpartisipasi dalam survei karena ketidaksesuaian bahasa. Dari Tabel 2 dapat dilihat bahwa hanya ada 22 artikel (21\%) dalam sampel penelitian kami yang melaporkan melakukan pre-test, empat artikel (4\%) menyatakan tidak melakukan pre-test, dan sebagian besar (80 artikel (75\%)) tidak melaporkan adanya pre-test.

\section{Response-rate}

Tidak ada kesepakatan mengenai berapa banyak response-rate yang dipertimbangkan untuk dapat diterima (acceptable) sehingga dapat merepresentasikan sebuah sampel. Sekaran dan Bougie (2010) mengatakan bahwa response-rate 30\% sudah dapat dipertimbangkan untuk diterima. Sedangkan Diamond (2000) menyatakan bahwa legal framework memberikan beberapa rule of thumbs mengenai tingkat response-rate yang dapat diterima, yaitu: response rate antara 75\%-90\% biasanya menghasilkan hasil yang reliable, meskipun peneliti seharusnya masih melakukan uji representasi sampel. Potensial bias mungkin terjadi apabila response-rate turun menjadi di bawah $75 \%$. Sedangkan apabila response-rate turun di bawah 50\% maka survei harus dipertimbangkan dengan hati-hati sebagai dasar pengambilan kesimpulan populasi.

Tabel 2 memperlihatkan bahwa ada empat artikel dalam sampel penelitian kami yang tidak melaporkan response-rate. Dengan mengabaikan keempat artikel tersebut, rata-rata response-rate adalah 30\%. Response-rate tertinggi adalah 100\% dan terendah adalah 9\%. Angka statistik tersebut tidak memenuhi standar legal seperti yang sudah dinyatakan di atas. Untuk menganalisis perkembangan response-rate penelitian akuntansi manajemen dan keperilakuan sejak tahun 1999-2012 yang dilakukan di Indonesia, kami membagi periode tersebut menjadi dua periode yaitu tahun 1999 - 2004 dan tahun 2005-2012. Pada periode tahun 1999-2004, rata-rata response-rate adalah 24\%, dengan response-rate tertinggi 79\% dan responserate terendah adalah $9 \%$. Sedangkan pada periode 2005-2012, rata-rata response-rate adalah 36\%, dengan response-rate tertinggi 100\% dan responserate terendah 9\%. Dari perbandingan tersebut terlihat bahwa response-rate dari periode 19992004 dan periode 2005-2012 menunjukkan perkembangan meskipun response-rate terendah masih sama.

\section{Prosedur Follow-up}

Jika tingkat response-rate yang tinggi tidak dapat dicapai di kesempatan pertama peneliti mengirimkan survei questionnaire-nya maka prosedur follow-up seharusnya dilakukan (Diamond 2000; Dillman 2007; Van der Stede et al. 2005; Cooper dan Schindler, 2008; Sekaran dan Bougie, 2010). Penelitian terdahulu menunjukkan bahwa follow-up secara efektif meningkatkan responserate (Sebagai contoh: Moore dan Tarnai 2002; Dillman 1978, 1999; Aryani 2009).

Rata-rata response-rate penelitian bidang akuntansi manajemen dan keperilakuan dalam sampel pengamatan kami adalah 30\%, dengan response-rate terendah adalah $9 \%$. Hasil ini cukup rendah apabila dibandingkan dengan standar minimal yang disyaratkan dalam rule-of thumb yang dinyatakan oleh Diamond (2000), sehingga sudah seharusnya peneliti melakukan prosedur follow-up untuk meningkatkan response-rate tersebut. Namun demikian, pada Tabel 2 terlihat bahwa hanya ada 17 artikel (16\%) dari total 106 
artikel dalam sampel kami yang melaporkan melakukan follow-up. Sebagian besar dari artikel tersebut (87 artikel (82\%)) tidak melaporkan prosedur follow-up, sementara ada 2 artikel (2\%) yang melaporkan tidak melakukan follow-up. Kedua artikel tersebut mempunyai response-rate yang sudah cukup tinggi yaitu $42 \%$ dan $54 \%$.

\section{Non-response Bias}

Meskipun tingginya response-rate tidak dapat disangkal merupakan refleksi ketepatan (rigor) suatu penelitian, response-rate itu sendiri bukanlah satu-satunya ukuran yang mewakili nonresponse error (Van der Stede et al. 2005). Response-rate menyajikan secara relatif jumlah responden, tetapi mengabaikan perbedaan antara responden dan jumlah sampel, yaitu non-response bias (Assael dan Keon 1982). Non-response survei berpengaruh pada kemampuan menggeneralisir hasil penelitian, namun hal ini tidak hanya tergantung pada response-rate, tetapi juga tergantung pada seberapa banyak responden berbeda secara sistematis dengan non-responden (non-response bias) (Groves 1989; Moore dan Tarnai 2002). Oleh karena itu, legal standar mensyaratkan adanya pembuktian pengaruh non-response pada hasil survei (Diamond 2000). Hal ini dikarenakan bahkan ketika response-rate rendah, hasilnya masih bisa digeneralisir jika tidak ada nonresponse bias atau non-response bias rendah (Van der Stede et al. 2005).

Dalam Tabel 2 dapat dilihat bahwa 57 artikel (54\%) dari total sampel kami mempunyai responserate antara 20\%-80\%, sehingga melakukan uji response bias merupakan hal yang penting untuk dilakukan karena ada kemungkinan target responden telah terpilih sendiri (self-selected) untuk merespon berdasarkan beberapa variabel yang diabaikan (omitted) yang terkorelasi, sehingga menimbulkan ancaman terhadap generalisasi hasilnya (Fowler 1984; Mangione 1995). Angka kisaran antara 20\%-80\% merupakan kisaran arbitrary karena belum adanya kesepakatan standar minimum response-rate yang dapat diterima (Fowler 1984). Lebih lanjut, Tabel 2 memperlihatkan bahwa hanya 31 artikel dari total 106 artikel (29\%) pada sampel kami yang melakukan uji nonresponse bias. Sebagian besar artikel (69 (65\%)) dari total sampel tidak melaporkan uji nonresponse bias, dan ada enam artikel yang melaporkan tidak melakukan uji non-response bias. Uji non-response bias yang dilakukan oleh 31 artikel tersebut adalah dengan membandingkan antara responden yang memberikan response awal dan akhir (early vs late respondents).
Pendekatan dengan membandingkan antara response awal (early respondent) dengan response akhir (late respondent) berdasarkan pada argumen bahwa late respondent kemungkinan besar sama dengan non-responden (Moore dan Tarnai 2002). Tetapi, semua artikel dalam sampel kami yang melakukan uji non-response-bias menyimpulkan bahwa sampel mereka tidak bias. Ketidakmampuan untuk mendeteksi adanya non-response bias dengan pendekatan early vs late respondents mungkin dikarenakan perbedaan sifat antara survei individual dan organisasional bukan karena masalah perbedaan waktu (early vs late) (Van der Stede et al. 2005). Lebih lanjut, Van der Stede et al. (2005) menyatakan bahwa syarat untuk melakukan uji non-response bias dengan pendekatan early us late respondent adalah bahwa peneliti sudah melakukan prosedur follow-up paling tidak sekali, sehingga response langsung dari responden sebelum dilakukan prosedur follow-up dapat dibandingkan dengan response yang diterima setelah dilakukan prosedur follow-up. Dari 31 artikel dalam sampel pengamatan kami yang melakukan uji non-response bias, hanya ada tujuh artikel yang juga melakukan prosedur follow-up.

\section{Tipe ukuran dependen variabel}

Salah satu pengamatan mengenai penelitian survei di bidang akuntansi manajemen dan keperilakuan adalah ketergantungan yang besar pada penggunaan self-report atau self-rating sebagai pengukuran dependen variabel. Meskipun pengukuran yang bersifat subyektif dapat menangkap persepsi responden tentang hal yang diteliti peneliti, ketergantungan yang besar pada pengukuran selfreport atau self-rating kemungkinan mengakibatkan kesalahan pengukuran (measurement error) karena bias subyektifitas (Birnberg et al. 1990). Ukuran self-report atau self-rating ini juga telah banyak dikritik karena kecenderungannya bagi responden untuk terlalu toleran pada dirinya sendiri yang mengakibatkan suatu kisaran kecil dari skor yang diamati (Prien dan Liske 1962; Thornton 1968; Mia 1989). Namun demikian, Brownell (1982a) menyatakan bahwa self-rating dapat mengatasi masalah 'halo error'. 'Halo error' adalah kecenderungan untuk mengevaluasi secara global atau dengan kata lain, untuk mengevaluasi hanya satu dimensi kognitif saja (Brownell 1982a).

Dari Tabel 2 dapat dilihat bahwa dari 106 artikel yang mengumpulkan data dependen variabel, 101 artikel (95\%) menggunakan self-rating/ self-report untuk konstruk kinerja (29 artikel) atau untuk konstruk variabel keperilakuan lain (misal: kepuasan pengguna, kepuasan kerja, dan lainlain) (72 artikel). Hanya ada dua artikel yang 
menggunakan ukuran obyektif kinerja keuangan (Fredianto, Ronie dan Zulaikha 2001, Ja'far, Muhammad S. dan Lisa Kartikasari 2008).

\section{Penyajian dan pelaporan}

Penyajian dan pelaporan dari suatu penelitian survei sangat diperlukan untuk meningkatkan kepercayaan akan hasil dari penelitian tersebut, seperti yang dinyatakan oleh Diamond (2000) bahwa kelengkapan dari pelaporan penelitian survei merupakan salah satu indikator layak dipercayanya suatu survei. Lebih lanjut, Van der Stede et al. (2005) menyatakan bahwa peneliti seharusnya paling tidak menyajikan dan melaporkan secara detail tentang tujuan survei, unit analisis, populasi dan sampel, rancangan pemilihan sampel dan responden, response-rate, penyusunan pertanyaan atau instrumen survei, dan ukuran validitas dan reliabilitas. Namun meskipun norma ini merupakan hal yang prakteknya dapat diterima untuk penelitian survei, tetapi detail proses pengumpulan data sesungguhnya dalam survei biasanya jarang diungkapkan dalam publikasi akademis, hal ini kemungkinan disebabkan karena batasan panjang artikel dalam suatu jurnal (Van der Stede et al. 2005).

\section{KESIMPULAN DAN SARAN}

Untuk menghasilkan suatu hasil penelitian yang dapat dipercaya, seorang peneliti harus melakukan segala upaya untuk meningkatkan kualitas data yang digunakan dalam penelitian tersebut apapun metode penelitian yang digunakannya. Melakukan penelitian survei yang berkualitas tinggi memerlukan seperangkat kondisi yang seringkali tidak semuanya dapat dikendalikan oleh peneliti. Groves (1989) menyatakan bahwa penelitian survei memerlukan populasi yang dapat diakses oleh peneliti, yang menggunakan bahasa umum, yang mau mendiskusikan banyak hal dengan orang asing (stranger), yang percaya pada janji tentang kerahasiaan. Kondisi semacam itu tampaknya semakin sulit untuk dipenuhi, tidak hanya pada penelitian di bidang akuntansi menejemen dan keperilakuan tetapi juga pada bidang lain dalam penelitian organisasional (Van der Stede et al. 2005).

Penelitian di bidang akuntansi manajemen dan keperilakuan yang dilakukan di Indonesia pada kurun waktu periode 1999-2012 tampaknya juga sudah menggunakan prosedur penelitian survei yang disarankan dalam banyak artikel atau buku-buku metode penelitian sehingga kualitas datanya dapat cukup dipertanggung jawabkan. Meskipun masih banyak artikel yang tidak secara lengkap melakukan semua prosedur yang disarankan dalam melakukan penelitian survei. Kami percaya bahwa penelitian bidang akuntansi manajemen dan keperilakuan akan memperoleh manfaat apabila kita sebagai peneliti bersedia untuk lebih berusaha mempelajari prinsip-prinsip mendasar dari metode penelitian tersebut dan menerapkannya dalam penelitian kita. Dengan semangat ini, kami berharap bahwa paper kami ini tidak dipandang sebagai hal yang menghakimi hasil penelitian yang sudah dilakukan maupun tidak dipandang sebagai hal yang memberikan pemecahan atas masalah yang mungkin ada, namun lebih pada sebagai wacana mengenai kualitas data dan bagaimana kita dapat memperolehnya dengan penelitian survei khususnya dengan survei mail questionnaire. Kami berharap bahwa paper ini akan meyakinkan kita bahwa masalah utama dalam penelitian survei terletak lebih pada bagaimana metode tersebut digunakan bukan pada metodenya sendiri. Seperti legal framework yang menyatakan bahwa data dari suatu survei yang dirancang dengan baik dan dilakukan dengan baik dapat diakui dan digunakan sebagi bukti dalam pengadilan (Diamond 2000).

\section{DAFTAR PUSTAKA}

Adli. (2001, Agustus). Asosiasi Sistem Kompensasi Insentif dan Motivasi Kerja Manajer dengan Misi Strategik Build sebagai Variabel Pemoderasi. Naskah dipresentasikan dalam Simposium Nasional Akuntansi IV, Bandung.

Aisyah, M. N., dan Sholihin, M. (2004, Desember). The Role of Organizational Commitment and Job-Relevant Information on the Relationship Between Budgetary Participation and Job Satisfaction. Naskah dipresentasikan dalam Simposium Nasional Akuntansi VII, Denpasar.

Alim, M. N. (2002, September). Pengaruh Ketidakpastian Stratejik dan Revisi Anggaran terhadap Efektivitas Partisipasi Penyusunan Anggaran: Pendekatan Kontinjensi. Naskah dipresentasikan dalam Simposium Nasional Akuntansi V, Semarang.

Alim, M. N., Hapsari, T., dan Purwanti, L. (2007, Juli). Pengaruh Kompetensi dan Independensi terhadap Kualitas Audit dengan Etika Auditor sebagai Variabel Moderasi. Naskah dipresentasikan dalam Simposium Nasional Akuntansi X, Makassar.

Amrul, S., dan Syar'ie, A. (2005, September). Analisis Beberapa Faktor yang Berpengaruh terhadap Proses Pengembangan Kualitas Sistem. Naskah dipresentasikan dalam Simposium Nasional Akuntansi VIII, Solo. 
Amrul, Sadat. (2004, Desember). Hubungan antara Partipasi dalam Pengembangan Sistem Informasi dengan Perkembangan Penggunaan Teknologi Informasi (Suatu Tinjauan dengan Dua Faktor Kontinjensi). Naskah dipresentasikan dalam Simposium Nasional Akuntansi VII, Denpasar.

Arifuddin, Anik, S., dan Wahyudin, Y. (2002, September). Analisis Pengaruh Komitmen Organisasi dan Keterlibatan Kerja terhadap Hubngan Etika Kerja Islam dengan Sikap Perubahan Organisasi (Studi Empiris terhadap Dosen Akuntansi pada Perguruan Tinggi Islam Swasta di Malang dan Makassar). Naskah dipresentasikan dalam Simposium Nasional Akuntansi V, Semarang.

Aryani, Y.A. (2009). The Effect of Fairness Perception of Performance Measurement in The Balanced Scorecard Environment, Thesis. Victoria University, Melbourne, Australia.

Assael, H. dan Keon, J. (1982). Nonsampling vs. sampling error in survey research. Journal of Marketing, 46(Spring), 114-123.

Astuti, P. D., dan Sabeni, A. (2005, September). Hubungan Intelectual Capital dan Business Performance dengan Diamond Specification: Sebuah Perspektif Akuntansi. Naskah dipresentasikan dalam Simposium Nasional Akuntansi VIII, Solo.

Aziza, N., Nasir, H. M., dan Daljono. (2006, Agustus). Hubungan Antara Risiko Manipulasi Earnings dan Risiko Corporate Governance Dengan Perencanaan Audit (Studi Empiris pada Auditor SE-Jawa). Naskah dipresentasikan dalam Simposium Nasional Akuntansi IX, Padang.

Berry, A., Loughton, E., and Otley, D. (1991). Control in a financial services company (RIF): A case study. Management Accounting Research, 2(2), 109-139.

Birnberg, J. G., Shields, M. D. dan Young, S. M. (1990). The case for multiple methods in empirical management accounting research (with an illustration from budget setting). Journal of Management Accounting Research, 2, 33-66.

Brownell, P. (1982a). A field study examination of budgetary participation and locus of control. The Accounting Review, 57(4): 766-793.

Brownell, P. (1982b). The role of accounting data in performance evaluation, budgetary participation, and organisational effectiveness. Journal of Accounting Research, 20(1) Spring, 12-27.

Budiwibowo, T., dan Ikhsan, A. (2003, Oktober). Pengaruh Strategik Kompetitif, Motivasi dan Budaya Kerja terhadap Hubungan antara Komitmen Organisasi kepada Karyawan dengan Kinerja Perusahaan. Naskah dipresentasikan dalam Simposium Nasional Akuntansi VI, Surabaya.

Budiyanto, E. T., Moh. Nasir, dan Indira, J. (2005, September). Pengujian Variabel-variabel yang Berpengaruh terhadap Ekspetasi Klien dalam Audit Judgment. Naskah dipresentasikan dalam Simposium Nasional Akuntansi VIII, Solo.

Cahyono, D. (2005, September). Pengaruh Mentoring terhadap Kepuasan Kerja, Konflik Peran, dan Prestasi Kerja serta Niatan untuk Pindah (Studi Empiris di Lingkungan Kantor Akuntan Publik). Naskah dipresentasikan dalam Simposium Nasional Akuntansi VIII, Solo.

Chenhall, R. H. (1997). Reliance on manufacturing performance measures, total quality management, and organizational performance. Management Accounting Research, 8(2), 187-206.

Cook, T. D.. and Campbell, D. T. (1979). Quasiexperimentation: design and analysis issues for field setting. Boston, MA: Houghton Mifflin.

Cooper, D.R. and Schindler, P.S. (2006). Business research method. The McGraw-Hill Companies, Inc.

de Vaus, D. A. (1992). Surveis in Social Research, London: Allen and Unwin.

Diamond, S. S. (2000). Reference guide on survei research. In reference manual on scientific evidence ( $2^{\text {nd }}$ ed., pp. 229-276). Washington, DC: The Federal Judicial Center.

Diana, N. (2003, Oktober). Analisis Hubungan Kompleksitas Organisasi, Keterlibatan Tim, Diversitas Ukuran Kinerja, Besar Kompensasi, Partisipasi terhadap Kinerja Tim. Naskah dipresentasikan dalam Simposium Nasional Akuntansi VI, Surabaya.

Dillman, D. A. (1978). Mail and Telephone Surveis: The Total Design Method. New York: Wiley.

Dillman, D.A. (1999). Mail and Internet Surveis: The Tailored Design Method. New York: Wiley.

Dillman, D. A. (2007). Mail and Internet Surveis: The Tailored Design Method, 2nd Edition, United States of America: John Wiley \& Sons, Inc.

Faisal. (2001, Agustus). Pengaruh Karakteristik Tugas terhadap Keefektian Bentuk Pengendalian Akuntansi, Perilaku dan Personal dalam Peningkatan Kinerja Manajer Riset dan Pengembangan. Naskah dipresentasikan dalam Simposium Nasional Akuntansi IV, Bandung.

Faisal. (2006, Agustus). Analisis Pengaruh Intensitas Persaingan dan Variabel Kontekstual terhadap Penggunaan Informasi Sistem Akuntansi Manajemen dan Kinerja Unit 
Bisnis dengan Pendekatan Partial Least Square. Naskah dipresentasikan dalam Simposium Nasional Akuntansi IX, Padang.

Fitriany, Lindawati Gany, dkk. (2010, Oktober). Analisis Faktor yang Mempengaruhi Job Satisfaction Auditor dan Hubungannya dengan Performance dan Keinginan Berpindah Kerja Auditor (Perbandingan pada KAP Besar, KAP Menengah dan KAP Kecil). Naskah dipresentasikan dalam Simposium Nasional Akuntansi XIII, Purwokerto.

Fowler, F. J. Jr. (1984). Survey Research Methods. Beverly Hills, CA: Sage Publications.

Fredianto, Ronie, dan Zulaikha. (2001, Agustus). Hubungan antara Lingkungan Eksternal, Orientasi Strategik dan Kinerja Perusahaan (Studi Terapan pada Industri Manufaktur Menengah-Kecil di Kotamadya Semarang). Naskah dipresentasikan dalam Simposium Nasional Akuntansi IV, Bandung.

Fuad, dan Sabeni, A. (2004, Desember). Budgetary slack and Its Antecedents Does manager's Power Distance Matter? Naskah dipresentasikan dalam Simposium Nasional Akuntansi VII, Denpasar.

Groves, R. M. (1989). Survey errors and survey costs. New York: Wiley.

Halimatusyadiah. (2003, Oktober). Pengaruh Gaya Kepemimpinan dan Kultur Organisasi terhadap Komunikasi dalam Tim Audit. Naskah dipresentasikan dalam Simposium Nasional Akuntansi VI, Surabaya.

Hariyanti, Widi, dan Moh. Nasir. (2002, September). Pengaruh Partisipasi Penyusunan Anggaran terhadap Kinerja Manajerial: Peran Kecukupan Anggaran dan Komitmen Organisasi sebagai Variabel Intervening. Naskah dipresentasikan dalam Simposium Nasional Akuntansi V, Semarang.

Henry, G. T. (1990). Practical Sampling. Newbury Park: Sage.

Hirst, M. K. (1983). Reliance on accounting performance measures, task uncertainty, and dysfunctional behaviour: Some extensions. Journal of Accounting Research, 21(2), 596605.

Hudayati, A. (2001, Agustus). Pengaruh Aspekaspek Penganggaran terhadap Konflik Peran Studi Empiris pada Perguruan Tinggi. Naskah dipresentasikan dalam Simposium Nasional Akuntansi IV, Bandung.

Ifada, L. M. (2008, Juli). Pengaruh Information Technology Relatedness terhadap Kinerja Perusahaan (Penelitian terhadap Perusahaan Perbankan di Jawa Tengah). Naskah dipresentasikan dalam Simposium Nasional Akuntansi XI, Pontianak.
Ifada, L. M., dan Kiswanto. (2010, Oktober). Pengelolaan Knowledge Management Capability dalam Memediasi Dukungan Information Technology Relatedness terhadap kinerja Perusahaan: Pendekatan Reflective Second Order Factor (Penelitian terhadap Perusahaan Perbankan di Jawa Tengah). Naskah dipresentasikan dalam Simposium Nasional Akuntansi XIII, Purwokerto.

Ikhsan, A., dan Rasdianto. (2005, September). Pengaruh Intervening Penggunaan sistem Akuntansi Manajemen dalam Hubungan antara Intensitas Persaingan Pasar terhadap Kinerja Unit Perusahaan. Naskah dipresentasikan dalam Simposium Nasional Akuntansi VIII, Solo.

Iman, V.K.N., dan Jogiyanto. (2006, Agustus). Pengaruh Penyelarasan Strategik terhadap Kinerja Organisasi pada Sektor Perbankan di Indonesia. Naskah dipresentasikan dalam Simposium Nasional Akuntansi IX, Padang.

Irawati, A., dan Supriyadi. (2012, September). Pengaruh Orientasi Etika pada Komitmen Profesional, Komitmen Organisasional dan Sensitivitas Etika Pemeriksa dengan Gender sebagai Variabel Pemoderasi. Naskah dipresentasikan dalam Simposium Nasional Akuntansi XV, Banjarmasin.

Ittner, C. D., and Larcker, D.F. (1995). Total quality management and the choice of information and reward systems. Journal of Accounting Research, 33(Supplement): 1-34.

Ittner, C. D., and Larcker, D.F. (1997). Quality strategy, strategic control systems, and organizational performance. Accounting, Organization and Society, 17(1), 17-35.

Ja'far S. Muh. dan Kartikasari, L. (2009, November). Carbonnaccounting: Implikasi Strategis Perekayasaan Akuntansi Manajemen. Naskah dipresentasikan dalam Simposium Nasional Akuntansi XII, Palembang.

Ja'far S. Muh., dan Kartikasari, L. (2008, Juli). Sistem Kontrol dan Kinerja: Pendekatan Interaksi dan Sistem untuk Riset Kontinjensi dalam Akuntansi Manajemen. Naskah dipresentasikan dalam Simposium Nasional Akuntansi XI, Pontianak.

Ja'far S. Moch., dan Dista, A.S. (2006, Agustus). Pengaruh Dorongan Manajemen lingkungan, Manajemen Lingkungan Proaktif dan Kinerja Lingkungan terhadap Public Enviromental Reporting. Naskah dipresentasikan dalam Simposium Nasional Akuntansi IX, Padang.

Januarti, Indira, dan Faisal. (2010, Oktober). Pengaruh Moral Reasoning dan Skeptisisme Profesional Auditor Pemerintah terhadap Kualitas Audit Laporan Keuangan Pemerin- 
tah Daerah. Naskah dipresentasikan dalam Simposium Nasional Akuntansi XIII, Purwokerto.

Jaya, Rizal. (2004, Desember). The Appropriateness of Conventional for Muslim Business Organizations: An Empirical Evidence on the Perception of Muslim Accounting Academicians in Yogyakarta-Indonesia. Naskah dipresentasikan dalam Simposium Nasional Akuntansi VII, Denpasar.

Jumaili, S., dan Gudono. (2006, Agustus). Hubungan Komponen Sistem Pengendalian Manajemen (Quality Goal, Quality Feedback, dan Quality Incentive) terhadap Kinerja Kualitas dan Konsekuensi terhadap Kinerja Keuangan. Naskah dipresentasikan dalam Simposium Nasional Akuntansi IX, Padang.

Kalagnanam, S. S., and Lindsay, R. M. (1999). The use of organic models of control in JT firms: Generalizing Woodward's findings to modern manufacturing systems. Accounting, Organizations and Society, 24(1), 1-30.

Kamal, M., dan Na'im, A. (1999, September). Pengaruh Perselisihan dalam Gaya Evaluasi Kinerja Anggaran terhadap kinerja: Tekanan Kerja dan Kepuasan Kerja sebagai Variabel Mediasi. Naskah dipresentasikan dalam Simposium Nasional Akuntansi II, Malang.

Kerlinger, F. N. (1986). Foundations of behavioral research. New York: CBS Publishing Japan, Ltd.

Kerlinger, F. N., and Lee, H. B. (2000). Foundations of behavioral research, $4^{\text {th }}$ Edition, United States of America: Wadsworth Thomson Learning, Inc.

Kiryanto. (2006, Agustus). Desain dan Pengaruh Sistem Kontrol: Pengujian Model Pengaruh Langsung dan Tidak Langsung. Naskah dipresentasikan dalam Simposium Nasional Akuntansi IX, Padang.

Komara, Acep. (2005, September). Analisis Faktorfaktor yang Mempengaruhi Kinerja Sistem Informasi Akuntansi. Naskah dipresentasikan dalam Simposium Nasional Akuntansi VIII, Solo.

Kurnianingsih, R. (2000, September). Pengaruh Sistem Pengukuran Kinerja dan Sistem Penghargaan terhadap Keefektifan Penerapan teknik TQM:Studi Empiris pada Perusahaan Manufaktur di Indonesia. Naskah dipresentasikan dalam Simposium Nasional Akuntansi III, Jakarta.

Kwok, W.C.C. dan Sharp, D.J. (1998). A review of construct measurement issues in behavioral accounting research. Journal of Accounting Literature, 17, 137-174.
Laksmi, Chairina, A., dan Indriantoro, N. (1999, September). Persepsi Akuntan Publik Lakilaki dan Perempuan terhadap Isu-isu yang Berkaitan dengan Akuntan Publik Perempuan. Naskah dipresentasikan dalam Simposium Nasional Akuntansi II, Malang.

Latuheru, B. P., dan Sabeni, A. (2004, Desember).Pengaruh Orientasi Profesional terhadap Konflik Peran dengan Variabel Moderating: Partisipasi Penyusunan Anggaran dan Orientasi Tujuan Sistem (Studi Empiris pada Perguruan Tinggi di Indonesia). Naskah dipresentasikan dalam Simposium Nasional Akuntansi VII, Denpasar.

Lau, E. A. (2003, Oktober). Pengaruh Partisipasi Pemakai terhadap Kepuasan Pemakai dalam Pengembangan Sistem Informasi dengan Lima Variabel Moderating. Naskah dipresentasikan dalam Simposium Nasional Akuntansi VI, Surabaya.

Lekatompessy, J. E., dan Chariri, A. (2003, Oktober). Analisis Variable-variabel Anteseden dan Konsekuensi Organizational-Professional Conflict Akuntan di KAP dan Industri. Naskah dipresentasikan dalam Simposium Nasional Akuntansi VI, Surabaya.

Lesmana, Sukma. (2003, Oktober). Pengaruh Ketidakpastian Lingkungan yang Dipersepsikan dan Strategi Kompetitif terhadap Hubungan Sistem Kontrol Akuntansi dengan Kinerja Perusahaan. Naskah dipresentasikan dalam Simposium Nasional Akuntansi VI, Surabaya.

Lestari, Wiyantoro, B. A., dan Retna, C. S. (2009, November). Pembagian Informasi Secara Vertikal dalam Budgeting Sharing dan Pengaruhnya terhadap Kinerja Manajerial (Kajian Empiris pada Perusahaan Manuaktur yang Listed di Bursa Efek Jakarta). Naskah dipresentasikan dalam Simposium Nasional Akuntansi XII, Palembang.

Limantara, F., dan Devie. (2003, Oktober). Kualitas Jasa Sistem Informasi dan Kepuasan para Pengguna Sistem Informasi. Naskah dipresentasikan dalam Simposium Nasional Akuntansi VI, Surabaya.

Lindrianasari, Jogiyanto, dkk. (2012, September). Kepribadian sebagai Pemoderasi Hubungan antara Persepsi CEO atas Kompensasi yang Diterima pada Keinginan CEO untuk Keluar Perusahaan secara Sukarela. Naskah dipresentasikan dalam Simposium Nasional Akuntansi XV, Banjarmasin.

Lindrianasari. (2000, September). Correlation between Expertise and Participation, and Correlation between Participation and Other Variables in Development Information System. 
Naskah dipresentasikan dalam Simposium Nasional Akuntansi III, Jakarta.

Lutf, J., dan Shields, M.D. (2003). Mapping management accounting: graphics and guideline for theory-consistent empirical research. Accounting, Organization and Society, 28: 169-249.

Maghfiroh, Siti. (2001, Agustus). Pengaruh Kultur Organisasi dan Pelatihan Profesional terhadap Hubungan Personalitas Individu dengan Kreatifitas: Studi pada "Kantor Akuntan Publik". Naskah dipresentasikan dalam Simposium Nasional Akuntansi IV, Bandung.

Maksum, A., dan Kholis, A. (2003, Oktober). Analisis tentang Pentingnya Tanggung Jawab dan Akuntansi Sosial Perusahaan (Corporate Responsbility and Social Accounting): Studi Empiris di Kota Medan. Naskah dipresentasikan dalam Simposium Nasional Akuntansi VI, Surabaya.

Malik, Suharno, L. S., dan Much. Syafrudin. (2010, Oktober). Komitmen Organisasional pada Dosen Akuntansi di Jawa Tengah. Naskah dipresentasikan dalam Simposium Nasional Akuntansi XIII, Purwokerto.

Mangione, T. W. 1995. Mail Surveis: Improving the Quality. Beverly Hills, CA: Sage Publications.

Mardiyah, A. A., dan Gudono. (2000, September). Pengaruh Ketidakpastian Lingkungan dan Desentralisasi terhadap Karakteristik Sistem Akuntansi Manajemen. Naskah dipresentasikan dalam Simposium Nasional Akuntansi III, Jakarta.

Mardiyah, A. A., dan Listianingsih. (2005, September). Pengaruh Sistem Pengukuran Kinerja, Sistem Reward, dan Profit Center terhadap Hubungan antara Total Quality Management dengan Kinerja Manajerial. Naskah dipresentasikan dalam Simposium Nasional Akuntansi VIII, Solo.

Marsh, C. (1982). The survei method, London: Goerge Allen and Unwin.

Martiningsih, Rr. Sri Pancawati. (2009, November). Studi Kebutuhan Informasi Pengguna Laporan Keuangan Pemerintah. Naskah dipresentasikan dalam Simposium Nasional Akuntansi XII, Palembang.

McGowan, A. S. and Klammer, T. P. (1997). Satisfaction with activity-based cost management implementation. Journal of Management Accounting Research, 9, 217-237.

Mia, L. (1989). The impact of participation in budgeting and job difficulty on managerial performance and work motivation: A research note. Accounting, Organization and Society, 14 (4), 347-357.

Moore, D. L., dan Tarnai, J. (2002). Evaluating nonresponse error in mail surveys. In R.M.
Groves, D. A. Dillman, J. L. Eltinge, dan R. J. A. Little (Eds.), Survey nonresponse (pp. 197211). New York: Wiley.

Moores, K., dan Yuen, S. (2001). Management accounting systems and organizational configuration: A life-cycle perspective. Accounting, Organizations and Society, 26(4/5): 351389.

Morgan, F.W. (1990). Judicial standards for survey research: an update and guidelines. Journal of Marketing, 54(1), 59-70.

Muawanah, Umi. (2000, September). Perilaku Auditor dalam Situasi Konflik Audit: Peran Locus of Control, Komitmen Profesi dan Kesadaran Etis. Naskah dipresentasikan dalam Simposium Nasional Akuntansi III, Jakarta.

Mulia, T.W., dan Indra, W.K. (2005, September). Pengujian Hambatan yang Dirasakan Terasuh dalam Hubungan Pementoran pada Kantor Akuntan Publik. Naskah dipresentasikan dalam Simposium Nasional Akuntansi VIII, Solo.

Mulyaningsih, N., dan Budiyanto, E.T. (2006, Agustus). Pengujian Variabel-variabel yang Berpengaruh terhadap Keinginan Klien untuk Mempengaruhi Kebijakan Audit. Naskah dipresentasikan dalam Simposium Nasional Akuntansi IX, Padang.

Murtiyani, Siti. (2001, Agustus). Pengaruh Sistem Penganggaran, Sistem Pelaporan dan Analisis, dalam Hubungan antara Partisipasi dengan Efisiensi dan Efektifitas Anggaran. Naskah dipresentasikan dalam Simposium Nasional Akuntansi IV, Bandung.

Muslichah. (2002, September). Pengaruh Teknologi Informasi, saling Ketergantungan, Karakteristik Sistem Akuntansi Manajemen terhadap Kinerja Manajerial. Naskah dipresentasikan dalam Simposium Nasional Akuntansi V, Semarang.

Mustikawati, Rr. I. (2006, Agustus). The Effect of Goal Orientation and Leadership Toward Management Accountant's Role in Business Decision Making and Adoption in New Management Accounting Technique. Naskah dipresentasikan dalam Simposium Nasional Akuntansi IX, Padang.

Musyarofah, Siti. (2003, Oktober). Pengaruh Penggunaan Anggaran dan Gaya Manajemen terhadap Hubungan antara Perubahan Strategik dan Kinerja Organisasi. Naskah dipresentasikan dalam Simposium Nasional Akuntansi VI, Surabaya.

Naim, A., Lau, C.M., dan Sholihin, M. (2003, Oktober). The Relationship between Multiple Measured-Based Perormance Evaluation and 
Managerial Performance: Role Procedural Fairness and Interpersonal Trust. Naskah dipresentasikan dalam Simposium Nasional Akuntansi VI, Surabaya.

Nasution, H., dan Fitriany. (2012, September). Pengaruh Beban kerja, pengalaman Audit dan Tipe Kepribadian terhadap Skeptisme Profesional dan Kemampuan Auditor dalam Mendeteksi Kecurangan. Naskah dipresentasikan dalam Simposium Nasional Akuntansi XV, Banjarmasin.

Nazari, J., Kline, T., and Herremans, I. (2006). Conducting survei research in management accounting, in Methodological Issues in Accounting Research: Theories and Methods, edited by Z. Hoque, pp. 427-459. London: Spiramus Press Ltd.

Nizarudin, Abu. (2006, Agustus). Pengaruh Strategi Custimization terhadap kinerja Perusahaan Melalui Penggunaan Karakteristik Informasi Sistem Akuntansi Manajemen yang bersiat Broad Scope dan Aggregation. Naskah dipresentasikan dalam Simposium Nasional Akuntansi IX, Padang.

Nor, Wahyudin. (2012, September). Pengaruh Fee Audit, Kompetensi Auditor dan Perubahan Kewenangan terhadap Motivasi Auditor. Naskah dipresentasikan dalam Simposium Nasional Akuntansi XV, Banjarmasin.

Nurahma, M., dan Indriantoro, N. (1999, September). Tindakan supervisi dan Kepuasan Kerja Akuntan Pemula di Kantor Akuntan Publik. Naskah dipresentasikan dalam Simposium Nasional Akuntansi II, Malang.

Nurkholis. (1999, September). Konsekuensi Ekonomik dari Regulasi Akuntansi Goodwill: Pengalaman Australia. Naskah dipresentasikan dalam Simposium Nasional Akuntansi II, Malang.

Papat, N., Ismail, T., dan Galih, F. M. (2012, September). Pengaruh Kerangka Levers of Control (LOC) dan Organizational Learning terhadap Peningkatan Organizational Performance (Studi Empiris pda Perusahaan Manufaktur di Provinsi Banten). Naskah dipresentasikan dalam Simposium Nasional Akuntansi XV, Banjarmasin.

Pinsonneault, A., and Kraemer, K. L. (1993). Survei research methodology in management information systems: An assessment. Journal of Management Information Systems, 10(2), 75-106.

Poerwanti, Tjahjaning. (2002, September). Pengaruh Partisipasi Penyusunan Anggaran terhadap Kinerja Manajerial: Budaya Organisasi dan Motivasi sebagai Variabel Moderating. Naskah dipresentasikan dalam Simposium Nasional Akuntansi V, Semarang.
Prasetyo, Priyono P. (2001, Agustus). Pengaruh Locus of Control Terhadap Hubungan Antara Ketidakpastian Lingkungan Dengan Karakteristik Sistem Informasi Akuntansi Manajemen. Naskah dipresentasikan dalam Simposium Nasional Akuntansi IV, Bandung.

Pratolo, Suryo. (2007, Juli). Good Corporate Governance dan Kinerja BUMN di Indonesia: Aspek Audit Manajemen dan Pengendalian Intern sebagai Variabel Eksogen serta Tinjauannya pada Jenis Perusahaan. Naskah dipresentasikan dalam Simposium Nasional Akuntansi X, Makassar.

Prien, E. P., dan Liske, R. E. (1962). Assessment of higher level personnel: III. A comparative analysis of supervisor ratings and incumbent self-ratings of job performance, Personnel Psychology, 15(2), 187-194.

Primasari, D., Waspodo, L., dan Rahman, S. (2008, Juli). Variabel Anteseden dan Konsekuensi Implementasi Sistem Informasi Keuangan Daerah (SIKD) (Studi Empiris pada Badan Koordinasi Wilayah Pembangunan Lintas Kabupaten/Kota Wilayah I Propinsi Jawa Tengah). Naskah dipresentasikan dalam Simposium Nasional Akuntansi XI, Pontianak.

Purbandari, T., dan Mujilan. (2012, September). The Organiszational Roles of Knowledge Sharing and Information Technology in the Commercial Banking Sector. Naskah dipresentasikan dalam Simposium Nasional Akuntansi XV, Banjarmasin.

Purnamasari, D. I., dan Kusuma, I. W., (2004, Desember). The Impact of The Participation and The Satisfaction of Users in the Development of the Information System with The Complexity of System and the Structure of Organizations as Moderating Variables. Naskah dipresentasikan dalam Simposium Nasional Akuntansi VII, Denpasar.

Purwanto, A., dan Hadiyati, S. N. (2011, Juli). Pengaruh Strategic Performance Measurement Systems terhadap Manager Performance dengan Job-Relevant Information, Role Ambiguity, Role Conflict, dan Burnout sebagai Variable Intervening (Studi Empiris pada Rumah Sakit Swasta di Wilayah Jawa Tengah). Naskah dipresentasikan dalam Simposium Nasional Akuntansi XIV, Banda Aceh.

Putra, E. P., dan Naim. A. (2000, September). Budaya Perusahaan dan Intesitas Peran Akuntansi Manajemen: Penelitian Empiris pada Perusahaan-perusahaan di Indonesia. Naskah dipresentasikan dalam Simposium Nasional Akuntansi III, Jakarta. 
Raharja, Surya. (2005, September). Studi Empiris Mengenai Penerapan Metode Sampling Audit dan Faktor-faktor yang Mempengaruhi Penggunaan Metode Sampling Audit oleh Auditor $B P K$. Naskah dipresentasikan dalam Simposium Nasional Akuntansi VIII, Solo.

Rahim, Syamsuri. (2003, Oktober). Hubungan antara Entrepreneurship Korporasi dengan Governance, Kepemilikan dan Manajemen Strategik: Studi Empiris Perusahaan-Perusahaan di BEJ. Naskah dipresentasikan dalam Simposium Nasional Akuntansi VI, Surabaya.

Rahman, F. A. (2002, September). Pengaruh Partisipasi Anggaran dan Keterlibatan Kerja terhadap Senjangan Anggaran dengan Komitmen Organisasi sebagai Variabel Moderating (Studi Empiris pada Kawasan Industri Batam). Naskah dipresentasikan dalam Simposium Nasional Akuntansi V, Semarang.

Ramdhani, B., Mukhlis, M., dan Bastian, E. (2011, Juli). Inovasi Produk dan Proses, Implikasi Akuntansi Manajemen lingkungan (Studi pada manajer Perusahaan Manufaktur di Banten). Naskah dipresentasikan dalam Simposium Nasional Akuntansi XIV, Banda Aceh.

Rasuli, M., dan Yunus, H. (2002, September). Hubungan Dua Konsekuensi Pengendalian Anggaran: Penciptaan Slack Anggaran dan Orientasi Manajerial Berjangka Pendek (Studi Empiris pada BUMN Indonesia). Naskah dipresentasikan dalam Simposium Nasional Akuntansi V, Semarang.

Ratmono, D., dan Prabowo, Y. H. (2006, Agustus). Komitmen dalam Hubungan Auditor dan Klien: Anteseden dan Konsekuensi. Naskah dipresentasikan dalam Simposium Nasional Akuntansi IX, Padang.

Ratmono, D., dan Nahartyo, E. (2012, September). Model Mediasi dan Moderasi dalam Hubungan antara Sistem Pengendalian Manajemen, Inovasi dan Kinerja. Naskah dipresentasikan dalam Simposium Nasional Akuntansi XV, Banjarmasin.

Respati, Novita W. (2011, Juli). Determinan Perilaku Manajer dalam Melakukan Kecurangan Penyajian Laporan Keuangan. Naskah dipresentasikan dalam Simposium Nasional Akuntansi XIV, Banda Aceh.

Restuningdiah, N., dan Indriantoro, N. (1999, September). Pengaruh Partisipasi terhadap Kepuasan Pemakai dalam Pengembangan Sistem Informasi dengan Kompleksitas Tugas, Komplesitas Sistem, dan Pengaruh Pemakai sebagai Moderating Varible. Naskah dipresentasikan dalam Simposium Nasional Akuntansi II, Malang.
Rimawati, Y., dan Wijanto, S. H. (2012, September). Keberhasilan Implementasi Elektronik Government Berdasarkan Persepsi Pengguna. Naskah dipresentasikan dalam Simposium Nasional Akuntansi XV, Banjarmasin.

Riyadi, S. (1999, September). Motivasi dan Pelimpahan Wewenang sebagai Variabel Moderating dalam Hubungan antara Partisipasi Penyusunan Anggaran dan Kinerja Manajerial. Naskah dipresentasikan dalam Simposium Nasional Akuntansi II, Malang.

Roberts, E. S. (1999). In defence of the survei method: An illustration from a study of user information satisfaction. Accounting and Finance 39 (1), 53-77.

Rusmana, Oman. (2003, Oktober). Sikap dan Niat Akuntan terhadap Internalisasi Informasi Lingkungan dalam Sistem Akuntansi Perusahaan. Naskah dipresentasikan dalam Simposium Nasional Akuntansi VI, Surabaya.

Sapsford, R. (1999). Survey Research. Thousand Oaks, CA: Sage Publications.

Sekaran, U., and Bougie, R. 2010. Research methods for business: A skill building approach. $5^{\text {th }}$ Edition. New York, John Willey\&Son Inc.

Sihwahjoeni, dan Gudono, M. (1999, September). Persepsi Akuntan terhadap Kode Etik Akuntan. Naskah dipresentasikan dalam Simposium Nasional Akuntansi II, Malang.

Singgih, E. M., dan Bawono, I. R. (2010, Oktober). Pengaruh Independensi, Pengalaman, Due Professional Care dan Akuntanbilitas terhadap Kualitas Audit (Studi pada Auditor di KAP "Big Four" di Indonesia). Naskah dipresentasikan dalam Simposium Nasional Akuntansi XIII, Purwokerto.

Solihin, M., dan Fathonah, S. (2004, Desember). The Role of Procedural Fairness on The Relationship Between Multiple Measured-Based Perormance Evaluation and Job-Related Tension. Naskah dipresentasikan dalam Simposium Nasional Akuntansi VII, Denpasar.

Sudman, S. and Blair, E. (1999). Sampling in the twenty-first century. Academy of Marketing Science, 27(2), 269-277.

Sunarta, I.N., dan Partiwi, D.A. (2005, September). Pengujian terhadap Technology-To-Performance Chain: Pendekatan Structural Equation Modeling. Naskah dipresentasikan dalam Simposium Nasional Akuntansi VIII, Solo.

Suprantiningrum, dan Zulaikha. (2003, Oktober). Pengaruh Total Quality Management terhadap Kinerja Manajerial dengan Sistem Pengukuran Kinerja dan Sistem Penghargaan (Reward) sebagai Variabel Moderating (Studi Empiris pada Hotel di Indonesia). Naskah dipresentasikan dalam Simposium Nasional Akuntansi VI, Surabaya. 
Supriyono, R. A., dan Syakhroza, A. (2003, Oktober). Peran Asimetri Informasi dan Peresponan Keinginan Sosial sebagai Variabel Moderating Hubungan antara Partisipasi Penganggaran dan Kinerja Manajer di Indonesia. Naskah dipresentasikan dalam Simposium Nasional Akuntansi VI, Surabaya.

Suryaningrum, D. H. (2003, Oktober). The Relationship Between User Participation and System Success: Study of Three Contigency Factors on BUMN in Indonesia. Naskah dipresentasikan dalam Simposium Nasional Akuntansi VI, Surabaya.

Swenson, D. (1995). The benefits of activity-based cost management to the manufacturing industry, Journal of Management Accounting Research, 7, 167-180.

Taniel, I. S., dan Manao, H. (1999, September). Analisis terhadap Faktor-faktor yang Berpengaruh pada Kepuasan Pemakai Accounting Software. Naskah dipresentasikan dalam Simposium Nasional Akuntansi II, Malang.

Thornton, G. C. (1968). The relationship between supervisory and self appraisal of executive performance. Personnel Psychology, 41, 441456.

Tjakrawala, F. X. Kurniawan. (2002, September). Pengujian Pengaruh Teknologi Komunikasi Sebagai Mediator terhadap Hubungan antara Atribut lingkungan dan Atribut Struktur Organisasi: Riset Empiris pada Perusahaan Manufaktur di Indonesia. Naskah dipresentasikan dalam Simposium Nasional Akuntansi V, Semarang.

Tjakrawala, F. X. K., dan Lukita, A. (2012, September). Model Kausalitas Critical Succes Factors dalam Implemetasi Sistem Enterprise Resource Planning guna Memberikan Net Benefit bagi Perusahaan dengan Menggunakan Partial least Square. Naskah dipresentasikan dalam Simposium Nasional Akuntansi XV, Banjarmasin.

Tjakrawala, F. X. K. dan Cahyo, A. (2010, Oktober). Adaptasi Model Delone \& Mclean yang Dimodifikasikan Guna Menguji Keberhasilan Implementasi Software Akuntansi bagi Individu Pengguna: Studi Empiris pada Perusahaan dalam Industri Barang Konsumsi yang Terdaftar di BEI. Naskah dipresentasikan dalam Simposium Nasional Akuntansi XIII, Purwokerto.

Utami, I., Syafrudin, M., dan Handayani, Rr. S. (2006, Agustus). Pengaruh Tekanan Etis terhadap Konflik Organisasional-Profesional dan Workoutcomes (Studi Empiris pada Akuntan Publik se Indonesia). Naskah dipresentasikan dalam Simposium Nasional Akuntansi IX, Padang.
Van der Stede, W. A., Young, S. M., and Chen, C. X. 2005. Assessing the quality of evidence in empirical management accounting research: The case of survei studies. Accounting, Organisations and Society, 30(7-8), 655-684.

Wahyudi, H., dan Mardiyah, A.A. (2006, Agustus). Pengaruh Profesionalisme Auditor terhadap Tingkat Materialitas dalam Pemeriksaan Laporan Keuangan. Naskah dipresentasikan dalam Simposium Nasional Akuntansi IX, Padang.

Wahyudin, M. (2003, Oktober). Persepsi Akuntan Publik dan Mahasiswa tentang Penerimaan Etika terhadap Praktik Manajemen Laba. Naskah dipresentasikan dalam Simposium Nasional Akuntansi VI, Surabaya.

Wiyantoro, L. S., Soerono, A. Y. dkk. (2009, November). Studi tentang Hubungan Sistem Pengukuran Kinerja Strategi Integrative, Penyelarasan Strategi Manufaktur, Pembelajaran Organisasional dan Hasil Akhir Strategi (Penelitian Empiris pada Manajer Perusahaan Industri Manufaktur di Banten). Naskah dipresentasikan dalam Simposium Nasional Akuntansi XII, Palembang.

Wiyantoro, L. S., dkk. (2011, Juli). Persepsi Auditor, Akuntan Pendidik dan Akuntan Manajemen tentang Konsep Dasar, Pengukuran dan pengungkapan Akuntansi Lingkungan. Naskah dipresentasikan dalam Simposium Nasional Akuntansi XIV, Banda Aceh.

Yeni, Nini Syofri. (2001, Agustus). Persepsi Mahasiswa, Auditor dan Pemakai Laporan Keuangan terhadap Peran dan Tanggung Jawab Auditor: Studi Empiris Mengenai Expectation Gap. Naskah dipresentasikan dalam Simposium Nasional Akuntansi IV, Bandung.

Young, S. M. (1996). Survei research in management accounting: A critical assessment, in Research Methods in Accounting: Issues and Debates, edited by, A. J. Richardson. CGA Canada Research Foundation.

Yuliana, Christina. (2010, Oktober). Peran Kepemimpinan dalam Pencapaian Kinerja Organisasi melalui Budaya, Strategi, dan Sistem Akuntansi Manajemen Organisasi. Naskah dipresentasikan dalam Simposium Nasional Akuntansi XIII, Purwokerto.

Yulianto, A. S., dan Wiyantoro, L. S. (2010, Oktober). Kajian tentang Pengaruh Pengembangan Kurikulum Akuntansi terhadap Kompetensi Lulusan Program Studi Akuntansi (Penelitian pada Auditor Junior Kantor Akuntan Publik di Jakarta). Naskah dipresentasikan dalam Simposium Nasional Akuntansi XIII, Purwokerto. 
Yuningsih. (2006, Agustus). The Effect of Exchange Relationship Quality on Manager's Task Performance in Multi-National Operations: The Role of Budget Emphasis as Moderator. Naskah dipresentasikan dalam Simposium Nasional Akuntansi IX, Padang.

Yusfaningrum, K., dan Ghozali, I. (2005, September). Analisis Pengaruh Partisipasi Anggaran terhadap Kinerja Manajerial Melalui Komitmen Tujuan Anggaran dan Job Relevant Information (JRI) sebagai variabel Intervening (Penelitian terhadap Perusahaan Manufaktur di Indonesia). Naskah dipresen- tasikan dalam Simposium Nasional Akuntansi VIII, Solo.

Yuvisa I. E., Rohman, H. A., dan Handayani. Rr. S. (2008, Juli). Pengaruh Identifikasi Auditor atas Klien Terhadap Objektivitas Auditor dengan Auditor Tenure, Client Importance, dan Client Image, sebagai Variabel Anteseden. Naskah dipresentasikan dalam Simposium Nasional Akuntansi XI, Pontianak.

Zimmerman, J. L. (2001). Conjectures regarding empirical managerial accounting research. Journal of Accounting and Economics, 32(13), 411-427. 